\title{
LA VILLA DE ILLUECA, DEL SEÑORÍO DE LOS MARTÍNEZ DE LUNA, EN EL SIGLO XV: SUS JUDÍOS *
}

\author{
ENCARNACIÓN MARÍN PADILLA
}

CSIC. Madrid

En el transcurso de la redacción de uno de mis trabajos de investigación ${ }^{1}$ que resultó más laborioso de lo que supuse que sería en un principio, dado el número de personas pertenecientes a las tres «leyes» religiosas que en él intervenían ${ }^{2}$, pensé que en un futuro volvería a referirme a una de las más importantes familias nobles aragonesas, los Luna o Martínez de Luna, como indistintamente aparecen nombrados ${ }^{3}$, linaje de ricos hombres, señores de los lugares o villas de Illueca y Arándiga entre otros, y a las comunidades judías que en su señorío se asentaron, de algunos de cuyos miembros ya había tenido noticias cuando redactaba mi tesis doctoral ${ }^{4}$. Desde entonces hasta hoy he ido recopilando material docu-

\footnotetext{
* En el próximo trabajo se estudiará la villa de Arándiga, del mismo señorío.

1 E. MARín PAdilla, "Antecedentes y resultados de una sentencia arbitral (siglo XV)», Anuario de Estudios medievales 14 (1984) 555-580.

${ }^{2}$ Doña Deanira de Luna y de Lanuza, viuda del señor de Illueca, y el prior y capítulo de canónigos de la iglesia de Santa María la Mayor o del Pilar, de Zaragoza, por parte cristiana; Caçon Namias, alias Cogulla, hijo de Namias Cogulla, judío de la villa de Illueca, por parte judía; y por parte mora, la aljama mora de Brea, lugar del que eran señores dichos prior y capítulo de canónigos.

${ }^{3}$ Resulta dificil poder asegurar, en ocasiones, a quién se refieren las noticias documentales, porque unas veces aluden a don Juan de Luna y otras a don Juan Martínez de Luna. Además, personas de la misma familia y con los mismos nombres y apellidos - padres, hijos, tíos y sobrinos-, aparecen conviviendo y, si al nombre y apellido no acompaña de dónde era señor, es poco menos que imposible aludir a determinados hechos con absoluta seguridad.

${ }^{4}$ E. MARf́n PADILla, Contribución al conocimiento de ritos y costumbres de conversos judaizantes aragoneses del siglo $X V$, según procesos inquisitoriales conservados en Zaragoza, [inédita].
} 
mental en los Archivos de Protocolos notariales aragoneses ${ }^{5}$, sobre dicha familia y aquellas personas que en su señorío residieron durante el siglo Xv; y aunque, como siempre ocurre con la documentación notarial, podré encontrar más noticias en invetigaciones futuras, creo que las que en este estudio presento son suficientes para dar a conocer algunos de los hechos más sobresalientes de los distintos señores Martínez de Luna que vivieron en dicho siglo y las comunidades cristianas, moras y sobre todo judías, que se establecieron en ambas villas o lugares ${ }^{6}$. Porque en Illueca y Arándiga no ocurrió como en otros lugares, -el caso por ejemplo de Brea, situado entre ambas villas, donde sus habitantes en el transcurso del siglo $\mathrm{XV}$ fueron sólo moros-, sino que sus moradores pertenecieron a las tres «leyes» religiosas. De ahí que, si la historia de Illueca y Arándiga estuvo íntimamente unida a la de los señores Martínez de Luna o Luna y estrechamente relacionada con la de otros lugares, Gotor, Purroy, Valtorres, La Vilueña, Villanueva, Chodes y Morata - también del señorío de los Luna-, la historia de sus judíos difícilmente puede separarse de la de los cristianos y moros que con ellos convivieron.

La villa de Illueca y su término se extiende sobre la vertiente septentrional de la Sierra de la Virgen; por su centro corre, en dirección N.O.-S.E., el río Aranda ${ }^{7}$, afluente del Jalón, muy cerca de la villa de Gotor, de la que también eran señores los Luna. Al sur de dicho río, el territorio es abrupto y al norte el suelo presenta

\footnotetext{
${ }^{5}$ Que se conservan en Zaragoza (Z.APN.), Calatayud (C.APN.) y La Almunia de Doña Godina (L.A.APN.). Después de las siglas, aparecerá el nombre del notario, año y folios; a veces, sólo el del comienzo del instrumento público estudiado cuando las fórmulas jurídicas empleadas - siempre las mismas, según la clase de instrumento y el notario ante el que se otorgaban - no interesen a la materia tratada, y finalmente, los testigos instrumentales cuando resulte de interés darlos a conocer. A dicho material documental he incorporado las noticias procedentes de procesos inquisitoriales que estuvieron en el Archivo de la Audiencia Territorial de Zaragoza (Z.AAT.); hoy en el Archivo Histórico de dicha ciudad. Detrás de dichas siglas, aparecerá el legajo, número, folios, fecha de testificación y testigos, si éstos fueran aclaratorios para la materia tratada. Las variantes ortográficas de apellidos y nombres de judíos y moros -que no acentúo- quedarán patentes en las notas. Las palabras hebreas o árabes aparecerán en cursiva y con la grafía de los documentos.

${ }^{6}$ Como indistintamente aparecen denominadas incluso en un mismo documento.

${ }^{7}$ Atraviesa los términos de Aranda del Moncayo, Jarque, Gotor, Illueca, Brea de Aragón, Nigüella y Arándiga.
} 
algunos cerros separados por pequeños barrancos y los valles de los ríos Isuela y Aranda. Rodeaban a la villa de Illueca, en el siglo XV, los términos de Brea, Sestrica, Gotor, Mesones y Jarque, y a dicha villa pertenecían los siguientes: la Huerta, donde se encontraban huertos, viñas y "pieças»; el Molino, con huertos que lindaban con el río; la Torre, con majuelos; la Puente, con huertos; la Espuela, con huertos y "pieças»; el Redondillo, con viñas; «la Cruzillada», con campos que lindaban con el «mont de todas partes», y «la Pezella», con viñas y majuelos. La villa de Illueca, antiguo solar y baronía de los Luna, se yergue sobre una prominencia del terreno del que sobresale el castillo-palacio mudéjar, donde transcurrió la niñez de don Pedro Martínez de Luna, el papa Benedicto XIII; mudéjar como el castillo es la iglesia dedicada a San Juan Bautista. Illueca, que fue y sigue siendo centro de una amplia comarca, dista $82 \mathrm{Km}$. de Zaragoza y 45 de Calatayud.

He dividido este estudio en dos partes, como queda recogido en el siguiente esquema:

1. Illueca en la primera mitad del siglo XV. Dependencias señoriales

Aljama judía: Organización

Censos, deudos y comandas que debe la aljama

2. Illueca en la segunda mitad del siglo Xv (1450-1492)

Aljama judía: Organización

Sinagoga

Carnicería

Censos, deudos y comandas que debe la aljama

Relaciones sociales

Familias judías

Conversos

\section{IllueCA EN LA PRIMERA MITAD DEL SIGLO XV. DePENDENCIAS}

SEÑORIALES

Durante los primeros doce años del siglo XV fue señor de la villa de Illueca ${ }^{8}$ don Juan Martínez de Luna, casado con doña Aldara

\footnotetext{
${ }^{8}$ El señorío de Illueca y Gotor pasó a pertenecer a la línea menor de los Martínez de Luna, concretamente a don Juan Martínez de Luna - podría llamarse II-,
} 
Rodríguez Cabeza de Vaca, de cuyo matrimonio nacerían don Juan, el primogénito, que sucedería a su padre en el señorío de Illueca; don Jaime, que heredó el señorío al morir su hermano sin hijos; y doña Contesina, entre otros.

Don Juan Martínez de Luna, señor del castillo y lugar de Illueca, compró, «si quiere", arrendó durante dos años y por siete mil florines de oro anuales, "todas las rendas e todos los fruytos et spleytes" que pertenecían al arzobispo de Toledo don Pedro en el obispado de Tortosa; además de «todas las rendas, fruytos e hemolumentes» que pertenecían a las preceptorías de la orden de San Juan del Hospital de Jerusalén y que tenía don Rodrigo de Luna, por el mismo plazo de tiempo y por mil florines de oro. En 1406, se acordaba la firma de los capítulos matrimoniales entre su hija doña Contesina de Luna, que se entregaría «arreada e enjoyada ... de todo aquel arreament que a ella pertenesce de su persona, et de arreamiente de cambra, segunt le conviente, et aquesto ultra los dezehueyto mil florines», y don Pedro Ximénez de Urrea ${ }^{9}$, señor de los lugares y castillos de Jarque, Sestrica, Tierga, Nuella y la casa de Lucena, que firmaría a la contrayente dicha cantidad, sobre sus lugares, y que pasaría al padre de la novia o sus herederos, si doña Contesina moría sin hijos. El acuerdo de dicho matrimonio iba a afectar - como acostumbraba ocurrir - a los lugares de ambos señoríos: en caso de litigio, reponderían, por parte de los Ximénez de Urrea, los concejos de cristianos y aljamas de moros de sus dichos lugares, y por parte de los Martínez de Luna, el castillo y lugar de Gotor, y los residentes en lugares del señorío, entre otros,

cuando contrajo matrimonio con María Pérez de Gotor, hija de Miguel Pérez de Gotor, señor de dichos lugares, y de María Pérez de Zapata, señora de Valtorres y La Vilueña. Era este Juan (II) hijo de don Juan Martínez de Luna (I), que murió a temprana edad -1309- y de doña Contesina de Calamanchana, que fue su tutora. Del matrimonio de don Juan Martínez de Luna (II) y de María Pérez de Gotor nacerían varias hijas, además de don Juan Martínez de Luna (III) y de don Pedro - el que sería papa Benedicto XIII. El heredero del señorío de Illueca y Gotor, Juan Martínez de Luna (III), casó en primeras nupcias con doña Teresa de Urrea y en segundas con doña Teresa de Albornoz, hija de Álvar García; del primer matrimonio nacería Juan Martínez de Luna (IV), el primer don Juan estudiado para este trabajo.

9 Señor del vizcondado de Rueda, de la villa de Épila, de dos partes del lugar de Suñén y de la tenencia de Alcalatén; a él me referí en E. MARín PAdiLla, «La villa aragonesa de Épila en el siglo XV: sus judios", Sefarad LIII (1993) 58-102, $72-77$ (en adelante «La villa de Épila»). 
los cristianos y moros del citado lugar, de Illueca -todavía no había judíos residentes en esta villa-, Morata y Villanueva, además de los judíos de Híjar Acach y Jehuda Chiniello, a quienes se les debian diversas cantidades. La muerte de doña Contesina, sin hijos, inició los problemas entre ambas familias nobles por el contencioso surgido en torno a "el dot, axuar e firma e particion de bienes" de ésta ${ }^{10}$. En 1410 , se tuvo que recurrir al nombramiento de árbitros "por bien de paz e de concordia" ", quienes en sólo unos días emitieron sentencia. Había transcurrido más de la mitad del 1411, cuando los Martínez de Luna y los Ximénez de Urrea concluían las prescripciones a las que les obligó la sentencia, que afectaban a los vasallos de sus respectivos lugares, entre los que se encontraban los cristianos y moros de Illueca, como he dicho. A don Juan Martínez de Luna le sucedió en el señorío su hijo don Juan ${ }^{12}$.

La vida de los habitantes de Illueca, cristianos y moros ${ }^{13}$, además de ir solucionando día a día sus propios asuntos, transcurría en torno a los hechos que acaecían en el castillo ${ }^{14} \mathrm{y}$ a las obligaciones que adquirían sus señores. Como en otros lugares de señorío, en Illueca, cuando los asuntos incumbían a todos sus moradores o el objeto de la reunión afectaba por igual a las tres comunidades, como ocurría cuando se vendía un censo, se recibía una comanda o surgían problemas relacionados con el señor, no se reunía cada

${ }^{10}$ Recuérdese el otro contencioso surgido entre ambas familias cuando doña Brianda de Luna abandonó a su marido don Lope Ximénez de Urrea y se unió a don Luis Cornel, aún antes de que se le concediera la anulación de su primer matrimonio. En 1412 doña Brianda era ya viuda de don Luis.

11 Los elegidos fueron el gobernador de Aragón mosén Gil Ruiz de Lihori, su hijo mosén Juan Fernández de Heredia, señor de Mara, y el ciudadano zaragozano y sabio en Derecho Domingo Lanaja.

12 Preparo en la actualidad un trabajo sobre la familia Martínez de Luna; esa es la razón de que, a veces, cuando me refiero a dichos señores, haya prescindido de recoger la base documental en notas.

13 Luego se verá que hasta la década de 1420 no aparecen documentados judíos con residencia en la villa.

14 En 1402 la casa de los Luna formaba un bando «en armas" contra los Urrea y don Juan Martínez de Luna y otros señores del reino estaban "haziendose» guerra unos contra otros, por lo que el reino se encontraba "tan alterado". En 1409 el papa Benedicto XIII envió a su sobrino don Juan Martínez de Luna, señor de Illueca, con cien hombres «de armas", a Sicilia; lo acompañaban su hermano don Rodrigo de Luna, que fue después Castellán de Amposta y otros caballeros del reino, escribe J. Zurita, Anales de la Corona de Aragón, Zaragoza 1668, t. 2, libro X, caps. LXXV y LXXXVII, págs. $437 \mathrm{v}-438$ y $451 \mathrm{v}$. 
comunidad por separado, la aljama de judíos en la sinagoga y la de los moros en la mezquita, sino que, junto con la comunidad cristiana, se congregaban "en el portegado" de la iglesia de San Juan ${ }^{15}$-en la misma iglesia en enero de $1444-$, o en la plaza de la villa ${ }^{16}$, llamada también plaza de los cristianos, convocados por voz del corredor público, generalmente cristiano, por determinados lugares de la villa, y avisados "a son de campana repicada", es decir, "por tanyimiento de canpana e publico pregon» a la puerta de la Iglesia o en ella. Allí, reunidos el concejo de los cristianos y ambas aljamas -al principio del siglo XV sólo la de los moros- deliberaban y tomaban acuerdos juntos, sin que parezca que existieran barreras de raza, «leyes» religiosas o costumbres. Moros, y después también judíos convivían pacíficamente con los cristianos, a los que les unían iguales intereses, y aunque cada uno de estos tres grupos sociales eran comunidades distintas de vecinos, ligados por vínculos religiosos, étnicos, jurídicos y consuetudinarios, disponían de análoga

${ }^{15}$ En 1403 se congregraron allí el justicia Lop de Albés junto con ocho vecinos, por parte cristiana, y los jurados don Mahoma el Catanyero y don Mahoma el Puro, junto al alamín don Ibraim de Farag, don Mahoma Busquavida, don Juce de Gali, don Ibraim el Borrego y don Mahoma el Alcaide, por parte mora, para reconocer que habían recibido en comanda de don Beltrán de Coscón, cuatrocientos veintitrés florines; scgún recoge F. MACHO Y ORTEGA, «Condición social de los mudéjares aragoneses (siglo XV)», en Memorias de la Facultad de Filosofia y Letras, Zaragoza 1923, T. I, 139-320, doc. 2, pág. 214. En 1445 vivía en Illueca el moro Juce de Gali, quizás hijo del citado don Juce. El 16 de marzo de dicho año Juce reconoció haber recibido en comanda del judio bilbilitano Simuel Alpastan cincuenta y tres sueldos cuatro dineros; respondió de dicha cantidad con sus casas de la villa que lindaban con las de Mahoma el Hapaco y la tienda del concejo (C.APN., Antón Martínez de la Justicia, 1445, fol. 86: uno de los testigos fue Ali el Tejedor, moro de Illueca).

16 El 19 de marzo de 1410 se congregaron alli, llamados por el corredor Juan Serrano, el justicia Domingo Fernández, los jurados Juan de Alfambra y Domingo Ximeno, y Esteban Gil, Martín Gil, Juan de Torralba, menor, don Climent Cristobal, Francisco López, Juan Pérez, Martín, Fernando López, Domingo Jurdán y Juan de Sirio, por parte cristiana, y el alamín Ibraym de Farax, los jurados Mahoma el Pozo y Juce el Cantarero, y Jahiel Almaloch, Hamet el Morisco, Jahiel Buscavida, Lop de Ferrero, Avdalla de Aranda, Ibraym de Lop, Mahoma el Catanyero, Mahoma Buscavida, Ibraym de Buscavida, Mahoma el Catanyero, menor, Ibraym de Buscavida, menor, Jahiel Çahot e Ibraym Durramen, por parte mora. Dicho día se reunieron también las aljamas moras de Gotor, con asistencia del procurador del señor, la de Sestrica y la de Novallas, para aprobar, lo mismo que hizo el concejo cristiano y la aljama mora de Illueca, la firma de dote que don Pedro Ximénez de Urrea hizo a su mujer doña «Condesa» de Luna, según recoge F. MACHO Y OrTEGA, "Condición social», doc. 6, págs. 216-218. 
organización administrativa, análogos funcionarios y atribuciones, régimen económico administrativo e impuestos.

Otros lugares comunes a dichas comunidades fueron: el molino del señor, que dio nombre a uno de los términos de Illueca, por cuyo uso pagaban los vecinos determinada cantidad ${ }^{17}$; el «forno de cocer pan del senyor" de la villa ${ }^{18}$, por cuyo uso se pagaba la "poya"; y la tienda del concejo, que lindaba con las casas del moro Yuce de Gali, donde es posible que tanto los moros como los judíos de la villa acudieran a comprar cuando lo necesitaran; la documentación vista no alude al lugar dónde pudiera estar la herrería, aunque en la villa residía Lop el Ferrero.

En Illueca no existieron diferentes barrios o calles donde sus moradores fueran sólo cristianos, moros, y luego judíos. Parece, sin embargo, por las noticias documentales, que algunos residentes prefirieron tener como colindantes a otros miembros de su misma comunidad religiosa. El lugar preferido para vivir fue, desde luego, la plaza de la villa, centro neurálgico de la vida social y económica de Illueca, donde vivieron cristianos, judíos y moros y de donde partirían al menos dos carreras públicas.

\section{Aljama judia: Organización}

La primera referencia documental a la aljama judía de la villa es del año 1424. En ella se cita textualmente a los «adelantados de los jodios de la aljama de jodios» de Illueca ${ }^{19}$. Cuatro años después

17 En 1421, el pueblo de Artasona y el de Olbera pagaban ciento diez sueldos por el treudo perpetuo del molino del señor (Z.APN., Martín de Tarba, Registro 1421, fol. 149v).

18 El 24 de enero de 1479, en Épila, el escudero y alcaide del lugar de Salillas Juan de Soria, que vivía en dicha villa, como procurador del escudero de Tarazona Luis de Viña - según poder hecho el 29 de diciembre de 1478, en Tarazona, ante el notario Andrés de Fuentes, que vivía en dicha ciudad-, vendió al escudero bilbilitano Martín de Sayas los bienes siguientes de su principal: unas casas en Illueca que lindaban con "el forno del senyor de la dita villa", con casas de Yunez Aym y con carrera pública; otras casas «tenientes a las sobre ditas", que lindaban con las anteriores, con el «dito forno», con casas de Martín Fortuño y con carrera pública; un huerto y una viña, sitos en la Huerta; y un campo en "las Cruzilladas». El precio, mil quinientos sueldos, otorgó haberlo recibido (Z.APN., Antón de Abiego, 1479, fols. $53-53 v$ ).

19 A ello me referiré extensamente en el apartado de censos, deudos y comandas. 
está fechada la primera alusión a un vasallo judío del lugar de Illueca, Jaco Azunana "de present» en la ciudad de Zaragoza. El 20 de abril de 1428, Jaco manifestó: — «me fago vassallo de vos el noble don Johan de Luna», «e vassallo del lugar de Illuecha» ${ }^{20}$, durante diez años, a partir de entonces; «et prometo pagar peyta e contribuyr con los jodios del dito lugar e no desvassallarme dius obligacion de todos mis bienes, etc.». La alusión a «jodios del dito lugar" vuelve a poner de manifiesto que ya moraban en Illueca judíos, junto con cristianos y moros, aunque no se sepa desde cuándo. Entre ellos: el matrimonio judío formado por Mosse $\mathrm{Al}$ malcani y su mujer Jamila, que eran vecinos de Illueca en 1429; Acach Moncati, rabí Simuel y su mujer Ester Manuel, que aparecen residiendo allí, aunque en 1433 el rabí ya había muerto; la viuda Mira Alazar, vecina de Illueca en 1434, cuando mantenía un pleito con el judío zaragozano Abraham Addich; y Mosse Alpastan que habitaba en Illueca en $1436^{21}$. Tanto Jaco Azunana, como Mosse Almalcani y su mujer Jamila, Mira Alazar y, tal vez, Mosse Alpastan, parece que habían pasado de una aljama de realengo, la de Zaragoza, a una de señorío, la de Illueca, como luego se verá.

El señor del que los citados judíos eran vasallos, don Juan Martínez de Luna, hijo de don Juan y doña Aldara, y marido de doña Brianda Maza, que le sobreviviría, fue camarlengo del rey don Alfonso, del que recibió algunas "gracias", entre otras, la jurisdicción criminal, mero y mixto imperio, de Brea y de Calatorao, lugares del prior y capítulos de canónigos de la iglesia de Santa María la Mayor, de Zaragoza, que tenían los oficiales de la villa real de Ricla; y dos mil florines de renta anual sobre las rentas y derechos

${ }^{20}$ El 3 de febrero de 1432, en Illueca, Hamet el Rovisco, moro que habitaba «de present» allí, se hizo vasallo del noble don Juan de Luna, señor de dicha villa, y vecíno de aquélla, etc. Juró, por «bille, etc., de seyer vuestro vasallo e seyervos leal vasallo e verdadero"; obligó su persona y bienes (Z.APN., Antón Melero, 1432, fol. 6). Meses después, el 6 de diciembre de 1433, en Zaragoza y en presencia del notario y testigos, compareció Sento Rogat, judio del lugar de El Frago, y ante el noble don Juan de Luna, señor de Illueca y de la mitad de El Frago, dijo que era vecino de este lugar y "vassallo por la meytad» del dicho señor y que "se devezinava del dito lugar de voluntat del dito senyor e se fazia su vassallo e vezino del lugar de Biel e prometia seyer su vassallo e verdadero etc.". Don Juan le dio licencia "de partirse" de El Frago «e acceptolo por vassallo suyo e vezino» de Biel (dicho notario, Registro 1433, fol. $49 \mathrm{v}$ ).

21 A todos ellos me referiré extensamente en el apartado de familias. 
reales en la villa de Morella y su comarca ${ }^{22}$. El señor de Illueca don Juan Martínez de Luna fue dueño de algunos inmuebles en la judería de Zaragoza: en 1421 , de unas casas ${ }^{23}$, que tenía a treudo Mosse Galaf y su mujer Mira ${ }^{24}$; en 1428 , de otras casas ${ }^{25}$ que tenían a treudo Jehuda Abenlupiel y Mosse Capacho, y de otras ${ }^{26}$ que se legaron en ese año a Acach Abnarrabi por trece florines, excepto «hun palaçuelo en el porche»; de otras con un «palaçuelo con la cambra sobre aquel ... enca la mano izquierda», que tenía a treudo Jehuda Carillo que, a su vez, las legó a Salamon Arrecopal por tres florines de oro; de otras ${ }^{27}$ con «hun palacio con una cambra sobre aquel con un paset po do entrar a la dita canbra e el tavlero que pueda tener en el porche cubierto de la dita casa", que lo tenía a treudo Jehuda Abenlupiel por tres florines de oro o treinta sueldos ${ }^{28}$; y de otras ${ }^{29}$, de las que también eran dueños los judios vecinos de Illueca Mosse Almalcani y su mujer Jamila, que el clérigo Martín de Lodosa, como procurador de don Juan y del matrimonio judío, vendió el 30 de junio de 1429, en Zaragoza, al mercader zaragozano Andrés Forcén por noventa y cinco florines de oro, que otorgó haber recibido ${ }^{30}$. Pero dejemos al señor de Illueca y volvamos a los judíos residentes en dicha villa.

Cuando el judío Jaco Azunana se hizo vasallo de don Juan, prometió "pagar peyta e contribuyr con los jodios del dicho lugar", pero ¿cuánta era la cantidad que de pecha pagaban los judíos de

\footnotetext{
${ }^{22}$ Se desconocen cuáles fueron las razones que movieron al señor de Illueca, don Juan, a hacer donación «pura, perfecta e irrevocable», de todos sus bienes, muebles e inmuebles, al escudero de su casa Antón Ximénez de Pueyo, en el año 1430, ante el notario que vivía en Zaragoza Martín Gil. El 30 de enero de 1431, en dicha ciudad, el citado escudero renunciaba a dicha donación y reconocía que se hizo "en fe»; obligó sus bienes (Z.APN., Antón Melero, 1431, fols. 3-3v).

${ }^{23}$ Lindaban con las del judío don Sento Caratiel, con las del converso Manuel de Caseda, con carrera pública y con callizo.

24 Z.APN., Salvador de Lafoz, 1421, fols. 165v-166.

25 Lindaban con las de Dolç Abnarrabi, con las de Salamon Alazar, el Niño, y con carrera pública.

${ }^{26}$ Lindaban con las de dicho Doly, con las de Aberros y con la plaza de Abnarrabi.

${ }^{27}$ Lindaban con las de dicho Dolç y, por dos partes, con la plaza de Abnarrabi.

28 Z.APN., Antón Melero, 1428, fols. 36v-37, 40, 41 y 76-76v.

29 Sitas en la judería, en la carrera de San Gil, lindaban con callizo sin salida, con cillero de don Nicolás Benedit, con las de Raciel y con dicha carrera.

${ }^{30}$ Z.APN., Antón Melero, 1429 , fols. $72 \mathrm{v}-73$.
} 
Illueca a los señores Martínez de Luna? No hay noticia concreta que a dicha cantidad aluda, pero se sabe que los adelantados y aljama de judíos de Biel ${ }^{31}$, pagaban anualmente dos mil sueldos a don Juan de Luna, en 1433 y $1438{ }^{32}$; en otros señoríos se pagaban de trescientos a ochocientos sueldos, más de «servicio gracioso» cien al año -el día de San Bartolomé, en agosto, el día de San Miguel, en septiembre o en Pascua Florida-, y en Navidad un pernil o un par de perniles de tocino y cinco pares de perdices ${ }^{33}$.

¿Qué obligaciones y derechos tenía el vasallo que durante un determinado número de años residía en el señorío de los Luna? No he hallado noticias que concretamente aludan a ello, pero en firmas de vasallaje con otros señores, durante ocho, diez o quince años, sí se especificaron: «yo vos dare ... a lavrar la meytat de cada sendas junadas, quebrar en un año e sembrar la otra meytat», «e de respondervosne al quartos e al qual quera»; «unas casas de las

31 El 29 de abril de 1428, el caballero de Zaragoza mosén Bernardo Coscón vendió al señor de Illueca don Juan Martínez de Luna «toda la part de las obras a mi pertenescient en el castiello de Biel", por quinientos florines; además prometió vender, por mil sueldos, su «part» de la villa de Biel. Al día siguiente, 30 de abril, ante el notario y testigos, se personaron los escuderos de Zaragoza Juan Sánchez y Sancho de Licerazo, alias Biel, y juraron, en presencia del noble don Juan y sobre la cruz, que le venderían «la part suya" de la villa de Biel y sus aldeas, desde entonces hasta el siguiente 8 de mayo, «empero dandole» mil florines; se comprometieron a no venderla a nadie durante dicho tiempo, bajo pena de perjuros e infames; don Juan pidió al notario que levantara acta y Francés Baro juró pagar a los escuderos, por el dicho noble, los mil florines en el plazo dicho. El siguiente 20 de julio, el escudero Antón Remírez de Funes vendió también a don Juan los lugares de Biel, Longares, Lobera e Isuerre, por tres mil quinientos florines. El 20 de agosto, don Juan encomendó el castillo y torre de su lugar de Biel al escudero de su casa Pedro Ruiz de Asín, para que recibiera «sagrament e homenaje» de sus vasallos (Z.APN., Antón Melero, 1428, fols. 35-35v, 36-50).

32 El 5 de diciembre de dicho año, en Zaragoza, los adelantados y aljama adelantaron la pecha de 1434, por necesidades del señor don Juan. Lo mismo ocurriría en 1438 , cuando a ruegos de su procurador «e por aferes e servicio» del señor don Jaime, adelantaron a éste los dos mil sueldos de 1439 (Z.APN., Antón Melero, 1433, fol. 47 y 1438 , fol. XXXVIII).

33 En 1421, los de Artasona pagaban de pecha a la señoría trescientos sueldos, más de «servicio gracioso" cien al año, el día de San Bartolomé, en agosto, y en Navidad un pernil de tocino y cinco pares de perdices; los de «Sietcastiella e de Orriergo» pagaban de pecha al señor setecientos sueldos, más cien «de servicio gracioso» al año, el día de San Miguel, en septiembre, y en Navidad un par de perniles de tocino y cinco pares de perdices; y los de Grostán ochocientos sueldos, más cien de «servicio gracioso» al año, en Pascua Florida, y en Navidad un par de perniles de tocino y cinco pares de perdices (Z.APN., Martín de Tarba, Registro 1421, fols. $149 \mathrm{v}-153$ ). 
quales me dades en cada un anyo» quince sueldos en Pascua de Nadal o en Santa María de Agosto; «medio cafiz de binya de la qual fagades» cinco sueldos el día de Todos los Santos; «hun guerto del qual fagades hun par de galinas» al final de cada año. Por su parte el vasallo, no saldría del lugar sin licencia, «por sus piedes o ajenos", "ni hiceria por el feyto de stoja»; obligaba su persona y bienes, bajo pena de quinientos sueldos para los cofres del señor; juraba, según su ley, dar todos los derechos al señor, todo provecho, librarle de daños, observar sus "regalias» y «que no puedan lavrar ni fer sementero en otro lugar...»; recibía en comanda del señor de treinta a cincuenta sueldos o cincuenta florines ${ }^{34}$, como garantía; y «tomamos homenage de manos e de boca de vos dito senyor» de ser leales vasallos y hacer todas las cosas de los demás vasallos del lugar ${ }^{35}$.

Si el matrimonio entre doña Contesina de Luna y don Pedro Ximénez de Urrea terminó en un pleito, el nombramiento de árbitros y una sentencia, que involucró al concejo de cristianos y aljama de moros de Illueca entre otros, algo semejante ocurrió, en 1429, aunque esta vez afectó a los judíos de Biel. Cuando contrajo matrimonio doña Leonor Hurtado de Mendoza - hija del difunto mayordomo mayor del rey de Castilla, don Juan Hurtado de Mendoza y de doña María de Luna, hermana del señor de Illueca don Juan- y don Felipe de Castro, menor - hijo de don Felipe de Castro o Felipe Galcerán de Castro, mayor, señor de la villa de Estadilla, y de doña Magdalena de Anglesola-, don Juan Martínez de Luna intervino, con consentimiento de su mujer doña Brianda Maza y de su hermana doña María, en la firma de los capítulos matrimoniales de doña Leonor y don Felipe, porque en el caso de no entregarse seis mil florines al contrayente en determinado plazo, respondería con los castillos y sus lugares de Biel, Longares, Isuerre y Lobera, su posesión y la jurisdicción civil y criminal. El 2 de febrero de

\footnotetext{
${ }^{34}$ Esta última cantidad solía entregar en comanda doña Brianda de Luna al moro que se hacía su vasallo durante diez años. Así ocurrió con Ibrahim de Lancari, moro que vivía en Plasencia y se hizo vasallo de Figueruelas, lugar de dicha señora (Z.APN., Lázaro Marcén, 1421, fol. 21).

${ }^{35}$ Z.APN., Salvador de Lafoz, 1432, fols. 63-63v, 352v-353 y 477v-478; y 1433, fols. 180-180v. A la relación entre vasallos y otros señores, los Ximénez de Urrea, me referí extensamente en E. Marín PADIlla, "La villa de Épila", Sefarad LIV (1994) $67-82$ y $307-332$.
} 
dicho año, los adelantados Sento Fayeva y Abraham Alfanchi, y Jehuda Loro, (?) Alfanchi, Bueno Rinan, Jacob Rinan, Simuel Java, Mosse de Sos, Jucef Ruetis, Acach Avritopal, Jehuda Nuleger «e de sí toda la aljama" de judíos de Biel, juraron que debían determinada cantidad a don Felipe de Castro, menor, como el concejo de cristianos de dicho lugar ${ }^{36}$. También las relaciones entre los Martínez de Luna y los Castro, en relación a este matrimonio, terminaron en un pleito, del que se nombró árbitro al hermano de don Juan y tío de doña Leonor, don Jaime Martínez de Luna, que sería luego señor de Illueca.

Se ha dicho que antes de que comenzara el segundo cuarto del siglo XV, la documentación consultada del año 1424 aludía por primera vez a los «adelantados de los jodios de la aljama de jodios» de Illueca, y que a partir de entonces se conocen los nombres de algunos de los judíos que residieron en la villa; la de 1444, año en que era alcaide Antón de Fuentes, proporciona noticias sobre los componentes de la aljama judía establecida en Illueca. La comunidad hebrea la presidían dos adelantados, Sento Frances y Nahamias Cogulla, y en caso de ausencia de uno de ellos, actuaba un lugarteniente de adelantado; es posible que alguno de ellos hiciera las veces de clavario y se ocupara de los asuntos económicos de la aljama. El resto de la comunidad judía lo formaban más de catorce judíos varones; algunos, por sus apellidos, podrían proceder de familias de la comunidad judía de Calatayud, como los Quatorze - Jehuda, Mosse y Salamon-, y los Alpastan -Abraham-, o de la de La Almunia de Doña Godina, como los Frances - Sento-; de otros, aunque sus apellidos aparezcan en diferentes lugares, villas y ciudades aragonesas, resulta más arriesgado aventurar su procedencia, como Salamon Atortox, Caçon Abendaut, Acach y Mosse Carrillo, Abraham Ceyt, mayor, Daniel y Acach Franco, Cey Moncati, Sento Najaran y Salamon de Utrilla ${ }^{37}$.

No hay noticia del inmueble donde la comunidad judía se reunía para hacer oración y resolver los asuntos propios de la aljama, ni se sabe quién fue la persona que ocupó el cargo de rabí cuando se

${ }^{36}$ Z.APN., Antón Melero, 1429, fols. 1-16. Años después, el arzobispado adquirió las tierras de Biel y su baronía a los señores de Illueca, don Juan Martínez de Luna y doña Sancha Guzmán, con la que casó en segundas nupcias.

${ }^{37}$ Más del doble eran los miembros de la aljama mora este mismo año. 
produjo la muerte de rabí Simuel; posiblemente éste y su sucesor desempeñarían el cargo de notario judío de la aljama.

\section{Censos, deudos y comandas que debe la aljama}

Aunque en alguna ocasión la familia Martínez de Luna, señores de Illueca, dieron comandas o las compraron y entregaron censos, con mayor frecuencia dicha familia y los lugares que constituían el señorío no pudieron hacer frente a sus gastos, necesidades y mantenimiento; de ahí que, según práctica común, recurrieran a la venta de censos o treudos perpetuos, que se arrastraban de señor en señor, si es que no eran cada vez de mayor cuantía, y a la petición de comandas a particulares. Con harta frecuencia, estos gravámenes eran reconocidos y admitidos por los miembros de los concejos de cristianos y de las aljamas de judíos y moros de los lugares del señorío, quienes quedaban endeudados de por vida, al igual que sus descendientes, a los compradores de esos censos o treudos ${ }^{38}$, a quienes daban las comandas, o a otras familias nobles con las que los Martínez de Luna emparentaron a través de matrimonios, como se ha visto. Ésta es la razón de que, al hacer referencia a las deudas de la aljama judía de Illueca, obligatoriamente se aluda a las contraídas por la familia Martínez de Luna y por el concejo de cristianos y la aljama de moros, pues sobre las tres comunidades recayeron, también, la mayoría de las veces.

En los primeros años del siglo $\mathrm{XV}$ las comunidades cristiana $\mathrm{y}$ mora de Illueca se habían reunido, conjuntamente, por asuntos relacionados con los señores Martínez de Luna, o para recibir comandas o censos ${ }^{39}$. En 1424, cuando ya estaba constituida en

\footnotetext{
38 A veces, cuando los señores recibían censos sobre "su tierra", la documentación referente al pago de los mismos o a acuerdos sobre ellos, no especifica sobre qué lugar o lugares recaían concretamente las deudas.

39 Señalo algunos: Los Martínez de Luna y los concejos y aljamas de Illueca, Gotor, Morata y Villanueva, vasallos suyos, pagaban un treudo perpetuo de mil sueldos al escudero zaragozano Fernando Díaz de Pomar; en 1406 lo recibió el procurador de éste, el judío Dolz Abnarrabi; en 1416 don Juan Martínez de Luna y sus lugares de Illueca, Gotor y Morata, pagaban cuatro mil sueldos censales, anuales, a dicho escudero. Los concejos y aljamas de Illueca, Gotor, Morata y Villanueva, junto con don Juan, su mujer Aldara, su hijo don Juan y su mujer Brianda de Maza, pagaban un censo anual y perpetuo de quinientos sueldos al escudero Galcerán de
} 
Illueca una aljama judía, el converso Luis de Santángel -antes Jehuda Chiniello-, que vivía en Híjar, se consideró pagado de las cuantías de dineros, florines $\mathbf{u}$ otros cualesquiera bienes muebles que don Juan de Luna y los jurados del concejo cristiano, «e encara los jurados e adelantados de los jodios de la aljama de jodios e de los moros» de dicho lugar y de Gotor, le debían; otorgó albarán, los consideró indemnes y defeneció al noble, a sus vasallos y a sus bienes, muebles e inmuebles. El débito ascendía a ochenta mil sueldos, que le debían en carta de deudo ${ }^{40}$.

En 1428, los concejos y aljamas de Illueca, Morata y Gotor, la morería de Terrer, La Vilueña y Valtorres, y el señor de ellos don Juan Martínez de Luna, recibieron del mercader converso zaragozano Gonzalvo de la Caballería cinco mil florines de oro en comanda. Salió fiadora doña María de Luna, viuda de don Juan Hurtado de Mendoza y hermana de don Juan, que entregó al mercader diversos bienes, entre otros, joyas y plata ${ }^{41}$, que Gonzalvo devolvió cuando le pagaron dicha cantidad ${ }^{42}$.

Don Jaime Martínez de Luna, señor de la villa y lugares de Illueca, Gotor, Arándiga, Chodes, Morata, Villanueva, Valtorres y La Vilueña, tras la muerte de su hermano don Juan sin hijos legítimos, había llegado a un acuerdo con su cuñada doña Brianda Maza un año después de la muerte de éste. El 1 de junio de 1439, en Zaragoza, el caballero Martín Díez de Aux, consejero del rey y justicia de Aragón, recibió de doña Brianda, a través del ciudadano converso y «sabio en dreito" de dicha ciudad Luis de Santángel, ciento ochenta florines de oro, por razón de la sentencia de dos contratos por los procesos hechos: un contrato de doce mil florines de oro que el noble don Jaime y los justicias, jurados de cristianos y

Tarba, señor de Asín. Los jurados y hombres buenos de los concejos de cristianos y aljamas de moros de Illueca y Morata, pagaban otro censo anual y perpetuo al también escudero zaragozano Pedro Ruiz de Moros. En 1416, el señor de Illueca y sus lugares pagaban de censo anual mil quinientos sueldos al prior del monasterio de los frailes Predicadores del convento de Zaragoza, el día de Todos los Santos.

${ }_{40}$ Z.APN., Martín de Tarba, 1424, fols. 504v y 525v-526.

41 Recuérdese que un año después don Juan Martínez de Luna intervenía en el contrato de matrimonio entre su sobrina doña Leonor Hurtado de Mendoza y don Felipe de Castro.

${ }^{42}$ El 14 de abril de 1433, en Zaragoza, se pagaron cuatro mil seiscientos treinta y cinco florines (Z.APN., Antón Melero, 1433, fols. 14v-17). 
aljamas de moros de Morata y Villanueva, habían prometido pagar, «apres dias vuestros», a quien la viuda ordenara; y otro contrato de mil florines de oro que don Jaime y las universidades, oficiales y hombres de sus lugares de Purujosa, Arándiga, Chodes, Morata y Villanueva, y la morería de Terrer, Valtorres y La Vilueña, pagarían anualmente a doña Brianda en tres tandas, durante «el tiempo de vuestra vida y viudedat» ${ }^{43}$. En esta ocasión, las obligaciones del señor de Illueca con la viuda de su hermano no afectaron a los residentes de la villa de Illueca. Cuatro años después, en 1443, don Jaime Martínez de Luna compareció ante notario para comunicarle que entre él y su cuñada doña Brianda «eran seydos firmados e jurados ciertos capitoles e pactos, etc., ... e se sperava fazer cierta jura mencionada en los ditos capitoles e atorgar otras cosas, por la dita razon, por la noble dona Sancha de Guzman», su mujer, ante notario. Por ello, lo requirió para que, cuando doña Sancha jurara e hiciera todos aquellos actos a los que estaba obligada, se lo comunicara por carta pública a doña Brianda; luego pidió al notario que levantara acta de lo expuesto ${ }^{44}$.

Se acercaba la segunda mitad del siglo XV, concretamente a comienzos de 1444 , cuando después de convocados ${ }^{45}$, se reunió el concejo de cristianos ${ }^{46}$ y las aljamas de moros ${ }^{47}$ y judíos, el 29 de enero en Illueca, en la iglesia de San Juan; con asistencia por parte

\footnotetext{
43 Se puntualizó que, aunque tenía «mayor derecho ... e por intercession de micer Luis ... helo dexado por los ditos" ciento ochenta florines, se daba por contento y pagado, y otorgaba albarán (Z.APN., Pedro de Torres, 1439, fols. 30-30v).

44 Z.APN., Domingo de Hecho, 1443, fols. 116-116v.

45 «A son de campana repicada» y por voz, «si quiere, clamamiento" del corredor público Pascual Fortuño, por orden del justicia, los jurados cristianos, el alcaide de la villa, adelantados judíos, alamín y jurados de dichas aljamas.

46 «De signo servicio, si quiere, de condicion». Asistieron el justicia Juan Burbano, los jurados Juan López, Antón Salabert y Juan Sánchez, junto con Juan de Ejea, mayor, Martín Burbano, Arango Adam y Gonzalvo Carano. En ocasiones, el apellido Burbano aparece escrito Urbano.

47 Asistieron el alamín Farax Cantarero, los jurados Brahem Haçan, Juce el Maxar y Ali Moraguas, junto con Brahem de Buscavida, mayor, Mahoma el Calderero, Brahem Buscavida, menor, Ali el Texedor, Mahoma el Arandino, Ali el Raqueno, Brahem de Almalequa, Ali Buscavida, Brahem de Gali, Ali el Cantarero, mayor, Juce Çaquano, Brahem el Hebri, Mahoma de Monim, Brahem de Zaym, Mahoma de Aladi, Brahem el maestro Ali (sic), Brahem el Ollero, Hamet el Horio, Mahoma Moragas, Mahoma Xixanta, Ali de Çale, Mahoma el Cantarero, Yuce de Cenia, Mahoma el Tacanyero, menor, Brahem el Morisco, Mahoma el Horio, Faraiq d'Espada, Avdalla el Ninelo, Mahoma el Texedor y Mahoma el Rey.
} 
judía del adelantado Sento Frances, el lugarteniente de adelantado Sabat Moncati, por el adelantado Nahamias Cogulla, y Caçon Abendaut, Acach Carrillo, Mosse Carrillo, Daniel Franco, Acach Franco, Mosse Quatorze, Salamon de Utrilla, Cey Moncati y Abraham Ceyt, mayor. Todos los reunidos, junto con el señor don Jaime Martínez de Luna y los vecinos de otros lugares del señorío ${ }^{48}$, vendieron a don Gonzalvo de la Caballería dos censos: uno, de novecientos sueldos por siete mil veinte de precio, y otro, de quinientos sesenta y siete sueldos un dinero por siete mil trescientos setenta y dos ${ }^{49}$.

\section{ILLUECA EN LA SEGUNDA MITAD DEL SIGLO XV (1450-1492)}

Cuando se iniciaba la segunda mitad del siglo XV, seguía siendo señor de Illueca el citado don Jaime Martínez de Luna. El 5 de septiembre de 1458, se otorgó carta de concordia entre don Jaime y su mujer doña Sancha de Guzmán con el judío Juce Hazan; y el siguiente 15 de noviembre don Jaime dio licencia a sus vasallos para que se obligaran a su mujer. A la muerte de don Jaime heredó el señorío su hijo don Pedro Martínez de Luna, que contrajo matrimonio con doña Deanira de Lanuza. De este matrimonio nacerían dos hijos, don Juan y don Jaime; ambos fueron señores de la villa de Illueca.

\section{Aljama judía: Organización}

Como he dicho, no existió en Illueca ni judería ni morería, barrios donde sólo moraran judíos o moros, respectivamente. En la década de 1450 el número de judíos varones residentes en la villa pudo llegar a unos veintidós, pero parece que se produjo un descenso entre 1460-1470. En 1476 componían la comunidad más de veintitrés

\footnotetext{
${ }^{48}$ Las aljamas de moros de Gotor, Chodes y Morata, el concejo general de cristianos, judíos y moros de Arándiga, el concejo de cristianos y aljama de moros de Villanueva, y los concejos de cristianos de Valtorres y La Vilueña, reunidos con posterioridad.

49 Z.APN., Pedro Sánchez de Calatayud, 1444, fols. 13-14; testigo con dos cristianos y el alfaquí Farax el Aladi, el judío de Illueca Salamon Atortox.
} 
judíos varones; y en los últimos doce años de permanencia en Illueca el número de judíos varones pudo estar alrededor de los treinta.

Seguían siendo dos los judíos a quienes se les asignaba el cargo de adelantado de la aljama, para que actuaran como representantes de la misma - Sabat Moncati y Juce Carrillo, en 1475, Abraham Bon y Simuel Alpastan, en 1483, y Mosse Quatorze y Acach Alguer, en 1492-; excepto en 1490, cuando se procedió a arrendar la carnicería de los judíos, que los adelantados eran tres - Caçon Cogulla, Abraham Ceyt, mayor, y Mosse Ceyt, mayor-, el número se mantuvo hasta la expulsión. No aparece nombrado ningún judío clavario, aunque se aludió a él en 1483; en este mismo año el judío Leon Quatorze actuó como procurador de la aljama, en 1490 lo hizo Abraham Ceyt y en 1492, Acach Moncati.

Otro rabí de Illueca, de nombre conocido, fue Acach de Calo. En 1475, actuó como notario de la aljama; hecho que puede explicar la frecuente comparecencia, por parte de los judíos de Illueca, ante notarios cristianos - muchos de ellos conversos--, y notarios judíos de Calatayud, para testificar instrumentos públicos, con algunos de los cuales mantenían frecuentes contactos por lazos de parentesco y amistad.

No aparece ningún médico judío residente en la villa, pero a finales de 1488 o en 1489, el físico maestre Jehuda Gargonia pudo haber cambiado su residencia de Calatayud a Illueca, aunque sólo fuera temporalmente.

Son pocos los oficios conocidos de los componentes de la comunidad judía de Illueca. En 1451 ejercía el oficio de tejedor Salamon de Utrilla ${ }^{50}$; en 1465 Jehuda Ceyt se dedica a la mercadería y gozaba de determinados privilegios, franquezas y libertades; en 1477 vivía allí el zapatero Abraham Acrix; y al nombre y apellido de Mosse Ceyt, suele acompañarlo el apelativo «el Cimaquero». Los judíos Juce Carrillo, Nahamias Cogulla, que tuvo casas en Calatayud, y su hijo Caçon Nahamias, alias Cogulla, se dedicaron, especialmente, a dar préstamos y comandas, como más adelante se verá. Es de

\footnotetext{
${ }^{\text {so }}$ La comunidad mora contaba con Ali el Tejedor, en la primera mitad del siglo XV, además de él, Hamet, Juce y Mahoma el Texedor, en la segunda mitad de dicho siglo.
} 
suponer que los miembros de la comunidad judía, como los de la cristiana, recurrirían cuando necesitaran útiles de cocina a la familia mora de los Cantareros ${ }^{51} \mathrm{y}$ de los Olleros ${ }^{52}$.

\section{Sinagoga}

Que los vasallos judíos acudieran cuando eran convocados, junto con los vasallos cristianos y moros, y que el sitio de reunión fuera la plaza, en el "portegado» de la iglesia de San Juan o en la misma iglesia, puede ser la causa de la falta de noticias sobre la sinagoga de la villa. De las reuniones propias de la aljama que en ella tuvieran lugar no se tiene noticia, pues se testificarían ante el notario judío o ante la persona que ejerciera sus funciones.

El edificio donde los judíos tuvieron su sinagoga estaba cerca del "forno de cozer pan" ${ }^{53}$ del señor de la villa. Sólo las casas del mercader bilbilitano Juan Díaz de Santa Clara mediaban entre uno y otro inmuebles en 1478; dichas casas lindaban también con las del judío Jehuda Ceyt y con dos carreras públicas.

En 1475 era rabí de la comunidad judía de Illueca el citado Acach de Calo, que desempeñó también las funciones de notario, como he dicho.

No consta las cofradías que pudo tener la comunidad judía de la villa ni dónde pudieron tener su sede, aunque en el arriendo de la carnicería de los judíos, en 1490, se mencionaron las "confrarias".

La documentación estudiada no menciona la existencia de un hospital judío ni de un cementerio.

\section{Carnicería}

Hasta 1483 no se tiene noticia documental de la «taula de la juderia» de Illueca. El 5 de septiembre de dicho año, el judío Acach

\footnotetext{
51 Juce el Cantarero, en la primera mitad del siglo XV y, además de él, Ali, Farax, Hamet y Homar el Cantarero, en la segunda mitad de dicho siglo.

52 Ali y Brahem el Ollero, en la segunda mitad del siglo XV. La comunidad mora contaba también con Ibrahim el Trampero y el barbero Ali el Arandino, en la segunda mitad del siglo XV, además del citado Lop el Ferrero.

53 En 1479, las casas que compró el escudero bilbilitano Martín de Sayas, lindaban con dicho "forno del senyor", con casas de Junez Aym y con carrera pública. Otras casas contiguas que también adquirió el escudero, lindaban con el horno, con casas de Martín Fortuño y con carrera pública.
} 
Alguer procedía a vender al zapatero bilbilitano Pedro Polo «todas las corambres que se mataran en la taula" dicha, buena corambre «de dar e recebir» y a los precios previamente convenidos: cabrunas machos a treinta y tres sueldos la docena; cabrunas hembras a veintitrés la docena; media lana y toda lana a quince la docena; y trasquilón y corderina a siete la docena ${ }^{54}$.

Dos años antes de la expulsión, concretamente el 4 de octubre de 1490, en Illueca, los adelantados de la aljama judía de la villa, Caçon Nahamias o Abennamias, alias Cogulla, Abraham Ceyt, mayor, y Mosse Ceyt, mayor, en nombre de la misma y certificados del correspondiente derecho, arrendaron la "carneceria de los judios" al cristiano Domingo Ximénez, vecino de Torralba, aldea de Calatayud. La arrendación se hizo por un año, a partir del anterior día de San Miguel, en septiembre, y los precios que se acordaron fueron los siguientes: "carnero ocho dineros y miaja la livra; crabon y cordero seys dineros y miaja la livra; baca, craba y ovexa quatro dineros y miaja la livra; el menudo de crabon y carnero siete dineros; el menudo de cordero sin cabeça cinco dineros, con cabeça siete dineros; el menudo de cabra y ovexa cinquo dineros». En la arrendación se impusieron ciertas condiciones a Domingo: tenía que tener «basta la carneceria de carne de carnero dende quinze dias antes de pascua florida de judios fasta por todo el mes de octobre et dende el dicho mes de octobre fasta la dicha pascua florida sia tovido matar dos carneros cada semana, excepto algunas fiestas, como son bodas, desposallas, confrarias, circuncisiones, que sia tovido el dicho carnicero matar carnero bastantment et eso mesmo por enfirmos»; «matar crabon, craba y ovexa en sus tiempos convenientes», según costumbre; «matar dos bueyes de premio durant el dicho tiempo y si mas querran» el aljama que esté en eleccion del dicho carnicero de matar mas, si querra»; si matara «carnero o cabron que sia castron, que lo pese un dinero menos por livra del precio suso dicho»; y «pesar la cabeça de cordero con la carne fasta tres dias del mes de mayo et no mas». Con estas condiciones, los adelantados prometieron mantener al carnicero en pacífica posesión de la carnicería, sin quitársela, obligando las rentas y bienes, muebles

${ }^{54}$ A ello me referiré más extensamente al hablar de Acach Alguer en el apartado de familias. 
e inmuebles, de la aljama. Domingo aceptó la arrendación en el tiempo y condiciones fijados, obligó también sus bienes, y juró cumplirlas ${ }^{55}$.

La firma de arrendación de la carnicería de los judíos en 1490, suponia que éstos tuvieran cubiertas sus necesidades de carne en la Pascua judía, en «bodas, desposallas, confrarias, circuncisiones» y para los enfermos de la comunidad, como habría ocurrido otros años, pero ¿quién era la persona encargada de proporcionar la carne kašer al arrendador cristiano?, ¿quién era el carnicero que sacrificaba los animales según los normas rituales, cortaba y despachaba la carne?, ¿de dónde procedían los animales que se mataban?, ¿dónde pastaban? La documentación vista no aclara ninguno de estos puntos ni aporta datos sobre la carnicería de los cristianos, que hubieran ayudado, quizás, a conocer algunas de las preguntas que quedan sin respuesta.

\section{Censos, deudos y comandas que debe la aljama}

Terminaba la primera mitad del siglo XV con la venta que algunos lugares del señorío de los Martínez de Luna, entre ellos el concejo de cristianos y las aljamas de judíos y moros de Illueca, hicieron a don Gonzalvo de la Caballería de un censo de novecientos sueldos y de otro de quinientos sesenta y siete sueldos un dinero.

Ya en la segunda mitad del siglo XV, concretamente el 24 de enero de 1455 , en Illueca y Gotor ${ }^{56}$, los concejos de cristianos y las aljamas de judíos y moros de dichos lugares, recibieron en comanda del mercader converso bilbilitano Juan Pérez de Santa $\mathrm{Fe}^{57}$ doce

${ }^{55}$ L.A.APN., Miguel Contín, 1490, fols. 66v-67. Comparando los precios de carnes y corambres vendidos en la judería de Illueca con los de la judería de Épila, en el transcurso del siglo XV, en general, acostumbran a ser más baratas las primeras (véase E. Marín PAdilla, "La villa de Épila», Sefarad LV [1995] 285-312).

56 Ante el notario Pedro Navarro, que vivía en Ateca.

57 Los judíos de Zaragoza Acach Abnarrabi y su mujer Sol Azamel fueron padres de Ezmel, Vidal, Jacob y Abraham Abnarrabi, y de Josuha, «agora clamado» Juan de Santa Fe. Acach hizo testamento en dicha ciudad, el 1 de junio de 1441, 12 del mes de civan año 5201 del cómputo judio, ante el notario judío de la aljama Juce Cahadias, en el que nombró a su mujer tutora y curadora de las personas y bienes de sus hijos. Cuando el 22 de febrero de 1443, dos cristianos recibieron a treudo unas casas, sitas en la parroquia de Santa María la Mayor de dicha ciudad, la viuda Sol, 
mil setecientos sesenta y seis sueldos ocho dineros; luego el converso vendería dicha comanda al escudero Fernando de Liñán, por cierto precio y bajo determinadas obligaciones, claúsulas y cautelas. El 10 de febrero de 1466, como a la aljama de los judíos de Illueca le correspondía pagar de dicha comanda setecientos sesenta y seis sueldos ocho dineros, el escudero prometió y se obligó a no demandar cosa alguna a la aljama ni a sus singulares, ni hacer «expensas ni execuciones», por esa razón ni por otra ${ }^{58}$.

Once años antes, concretamente el 25 de abril de 1455, los judíos de Illueca acudieron, como aljama, a la comparecencia de todos los vecinos de la villa, dado que la penuria de medios económicos se dejaba sentir en las tres comunidades por igual ${ }^{59}$. Dicho día se encontraba

plegado y ajustado el concejo de cristianos y las aljamas de judios y moros ..., devant de la puerta de la eglesia del senyor Sant Johan, alli do otras vegadas ... son stados et costumbre de plegar e de ajustar por fazer tales o senblantes actos, segunt que del dito clamamiento, si quiere, ajustamiento fizo fe e relacion

el corredor público del lugar Pascual Fortuño,

el haver cridado el dito concello e aljamas ... pora la hora, si quiere, lugar, por mandamiento a el expreso por el justicia e jurados, si quiere, alamin e jurados de moros e adelantados de la aljama de los ditos judios ..., en el qual ajustamiento, si quiere plegamiento fueron alli personalment... ${ }^{60}$;

en su propio nombre y como tutora y curadora, regidora y administradora, renunció a cualquier derecho que tuviera sobre ellas (Z.APN., Salvador de Lafoz, 1443, fols. $139 \mathrm{v}-140)$.

58 C.APN., Leonardo de Santa Fe, 1466, fols. $43 v-44$.

59 Pero fueron los moros y sus aljamas los que con mayor frecuencia recurrieron a la venta de censos y peticiones de comandas, contrayendo enormes deudas que los dejaba a merced de las usuras, muchas veces de judios y conversos, que los agobiaban y arruinaban sus vidas.

${ }^{60}$ Por el concejo cristiano: el justicia Juan Urbano, los jurados Juan de Haro y Pedro Suárez, y Antón Urbano, Juan Ejea, Domingo Ferrando, Martín Inés y Pedro Valls. Por la aljama mora: el alamín Farax el Cantarero, los jurados Ali el Texedor y Ali Buscavida, «e Ybrahem de Almalequa, Ybrahem el Morisco, Mahoma de Monin, Ali Almalequa, Ybrahem de Gale, Mahoma el Haladi, Ybrahim el Ollero, Mahoma el Arandino, Ybrahem de Aladi, Juce el Maxon, Hamet el Haladi, Hamet el Horio e Mahoma el Hapago». 
por parte judía: los adelantados Bienbenist Abenpessat y Sento Frances, y Mosse Ceyt, mayor, Simuel Cogulla, Leon Quatorze, Juce Ceyt y Acach Carrillo. Todos los reunidos, sin discrepancia alguna, consideraron que tenían que

soportar grandes e incontables cargos que ... han sustenido daqua daqui e de cada dia sostenimos por muytas e diversas quantias de dineros los quales fueron manlevados en los tiempos pasados a grandes logros ... Et encara por muytas e diversas otras justas causas, si quiere, razones a los infrascriptos fazer inducientes, havido sobre aquesto diligentement tractado et contractado con maduro consello. Et ayamos feyto exponer, si quiere, meter venales por diversas ciudades, villas e lugares del Regno de Aragon, el dito censal por diversos corredores de las sobre ditas ciudades, villas e lugares sobre ditos. Et no ayamos trobado ni trobamos qui tanto precio se aya offrecido dar ni de en el dito censsal como vos el muyt honorable e discreto don Ochona de Ortubia ..., que nos prometiesteres e vos offreciesteres e prometiesteres dar en el dito censal el precio, si quiere, quantia de la part de iusoscripto.

Por tanto, todos los reunidos, en sus propios nombres,

por si et por el todo ..., de nuestras sciertas sciencias e agradables voluntades e certefficados plenament de todos los dreytos de los ditos concellos e aljamas de los sobre ditos lugares ${ }^{61}$ e de los singlares de aquellos e aquellos por nos todos los que de present somos presentes como de los absentes e de todos los qui por tiempo seran de los ditos lugares con titol e testimonio verdadero de aquesta present carta publica de vendicion a todos tiempos jamas firme $e$ valedera e en ninguna cosa no revocadera, vendemos e luego de present livramos, si quiere, desenparamos, atorgamos et encara asignamos a vos ..., asi como a mas dant e offrecient e a los vuestros en aquesto herederos e succesores e a todos aquellos que vos querreredes, hordenareredes, et mandareredes cincientos solidos ..., buena moneda corrible en el Regno de Aragon ..., censales, anuales, rendales, si quiere, de cens e trehudo perpetuo, francos de toda carga e servitut e de toda obligacion e de todos donos, prefiertas, excepcio-

${ }^{61}$ El mismo día tuvo lugar en Arándiga una reunión del concejo cristiano y aljamas judía y mora por el mismo motivo y con idéntico objeto. 
nes, contribuciones, inpossiciones, cenas, peytas, cavallerias ${ }^{62}$ e de todas e qualesquiere otras cargas reales e vezinales e de todos marques, enparas, sequestraciones e de todos e qualesquiere otros inpedimentos, empero sines de fadiga, loysmo e comisso havederos e recebideros.

Cristianos, judíos y moros respondieron del censo vendido con todos sus bienes particulares,

en e sobre todos e qualesquiere casales, molinos, molinares, deffessas, fornos, vinyas, campos, tierras, possesiones, deudos, rendas, trehudos, censales, violarios, dreytos, nombres e acciones, ganados bestiares grosos et menudos, bestias de cavalgar e de arar, porquerias, adulas e yeguacerias, baxiellos de fust, de tierra e qualesquiere otras joyas, de oro e de argent, de covre, de allaton, de stanyo, ropas, vestiduras de drap, doro, de seda e de lana e otros qualesquiere bienes e cosas mobles e sedientes, privilegiados o non privilegiados.

Dicho censo lo pagarían anualmente, a partir del año siguiente, el día de San Marcos Evangelista, 5 de abril, en las casas que el escudero Ochona tenía en Épila,

\footnotetext{
62 La familia Martínez de Luna tenía derecho por «gracia e concession» del rey don Martín a treinta caballerías «donor acostumbradas haver por los nobles d'Aragon", según constaba en un privilegio fechado el 24 de marzo de 1398, en Zaragoza, en favor del entonces señor de Illueca don Juan Martínez de Luna. Con posterioridad, el rey don Fernando otorgó la misma concesión en privilegio fechado el 16 de octubre de 1412 , posiblemente al producirse la muerte de su titular; privilegio confirmado por el rey don Alfonso el 2 de mayo de 1416, en el monasterio de Poblet, en favor del hijo de don Juan. Los titulares de la familia Martínez de Luna, beneficiarios de dichas caballerías, asignaron algunas de ellas a un particular, aragonés e infanzón, «attendidos los muytos agradables plazeres, servicios, honras e buenos merecimientos", de él recibidos. En la donación se consignó sobre quién o quiénes recaía el gravámen, la cantidad que se pagaría, la fecha de pago y que «por la qual cavalleria vos ... siaredes tenido servir o sirvades toda vegada que requerido o tenido segunt fuero e costumbre del Regno de Aragon ... por afferes e servicio del senyor Rey con nos empero o en nuestra conpanya e por indisposicion nuestra con qui nos bos diremos o assignaremos con hun cavallo armado segunt fuero de Aragon...». El beneficiario, una vez aceptada la caballería, juraba por la cruz y los santos cuatro evangelios por él tocados, es decir, hacía «sagrament e homenage de manos e boca de servir con un caballo armado...", ante el noble don Juan Martínez de Luna o su procurador. Pese al juramento, no siempre los beneficiarios cumplieron sus obligaciones. Las caballerías fueron objeto de venta, arriendo y motivo de pleitos entre los nobles. Los Martínez de Luna tuvieron derecho, entre otras, a las siguientes caballerías: una, sobre la aljama de judíos de Uncastillo y sus oficiales; trescientos sueldos al año, a pagar en dos tandas, en enero y el día de San Juan Bautista; otra, sobre la aljama de judíos de Zaragoza; y una tercera, sobre la aljama de judíos de Tauste.
} 
a todo ariscle, periglo, fortuna e propias missiones e expensas nuestras e de los nuestros et de los ditos concellos e aljamas.

El precio, cinco mil sueldos, otorgaron haberlo recibido; renunciaron a

toda e qualquiere excepcion de frau e de enganyo e de no haver havido, si quiere, contado en poder nuestros e de cada uno de nos.

La pena por impago sería de cien sueldos, a dividir en tres partes iguales, una para el señor don Jaime de Luna y las otras dos, para el comprador. Recibieron, además,

en nos e en los nuestros qualquiere caso fortunal de agua, fuego, enemigos o cometimiento alguno de ladrones e otros qualesquiere casos accidentales por los quales a vos dito comprador e a los vuestros la paga del dito cens, si quiere, trehudo perpetuo o partida alguna de aquel se pudiese alargar, proceder e tirar o enbargar.

Pagarían mensajeros o procuradores del comprador que, por culpa de ellos, tuvieran que salir de Épila, y sus salarios, diez sueldos al día; y en un plazo de tres días se elegirían "dos personas de cada braço" del lugar de Illueca, como del de Arándiga, a saber: de los cristianos, el justicia y uno de los jurados, de los judíos, "uno de los adelantados con otro judio de los millores de la juderia", y de los moros, "el alamin con otro moro de los millores e mas abonados",

a fin que sian por todo dotze personas, a saber ys del lugar de Arandiga seys personas e del lugar de Illuequa otras seys personas e que sian todos casa stantes de cada uno de los ditos lugares, de los qui agora somos o por tiempo seramos,

los que el comprador o sus sucesores «querreredes, ordenareredes e mandareredes, podaderes mudar e variar». Los elegidos tendrían en Zaragoza

los ostages ..., dentro de la claustra del monesterio de Sant Francisco de los freyres menores de la dita ciudat e de dentro de aquella no salliremos ni salliran por nuestros propios ni suyos piedes ni por 
ninguno allenos, de grado ni por fuerça, paladinament ni scondida, de dia ni de nueyt, por tierra ni por agua ni por alguno otro buenho ni malo ingenio ni mala art ni enganyo, sino ys e sera con expresa licencia voluntat e mandamiento vuestro e de los vuestros, la qual licencia aya a constar e parecer por carta publica feyta por notario publico ...; si por ventura los ditos seys honbres de cada un lugar ..., de los ditos concellos ... e aljamas ... sleydos e nombrados a tener los ditos ostages o alguno dellos no yran a tener aquellos de dentro de tres dias continuos apres que la dita requisicion por vos ... e por los vuestros o procurador ... a los ditos dotze electos ... sera de palavra o por scripto o de ydos seran, no teneremos o teneran, cumpliremos o cumpliran aquellos e teniendo e cumpliendo los sobre ditos hostages nos partiremos o se partiran, salliremos o salliran sines de voluntat, licencia e expreso consentimiento de vos dito Ochona ... o de los vuestros ..., a tanto que vos ... siaredes entregament satisfeytos, contentos e pagados de los ditos cincientos solidos...

Las penas las cobrarían de ellos y de sus bienes, pero

no puedan seyer levadas ni demandadas por part del dito senyor don Jayme de Luna, senyor nuestro, sino con voluntat e expreso consentimiento de vos dito comprador o de los vuestros...

El documento concluía con las fórmulas jurídicas acostumbradas que aseguraban absoluta garantía al comprador, entre otras: que «siaredes creydos por vuestra e suya sola sinple palavra sines de testimonios e jura" y que éste o los suyos elegirían los jueces en caso de pleitos, pues ellos renunciaron a firmas de derecho y a su juez ordinario y local. Finalmente todos juraron «de no firmar de dreyto ni de plytehar contra la sobre dita vendicion»: los cristianos, por la cruz y los santos cuatro evangelios; los judíos, sobre la ley de Moisés; y los moros, "por bille Alladi Illeha Illehua». El señor de ambos lugares, don Jaime de Luna, que se encontraba en Arándiga, aprobó y loó la venta del censal, y dio su autorización ${ }^{63}$.

Después de la venta del censal todos los bienes, muebles e inmuebles, de las tres comunidades religiosas de Illueca, minuciosa-

${ }^{63}$ L.A.APN., Martín de Marín, 1455, fols. 64-80; testigos: el epilense Juan de Riello, el judío de Illueca Simuel Çarffati y el moro de Morata Ali el Ferrero. 
mente especificados, quedaron como garantes. Pero tres días después de efectuada ésta, el escudero Ochona de Ortubia,

por algunas razones ad aquesto mi voluntat induzientes, de mi scierta sciencia atorgo e me plaze bien que toda [hora] e quando los sobre ditos concellos, si quiere, aljamas ..., querran de mi el sobre dito cens, si quiere, trehudo perpetuo a mi vendido, lo puedan quitar contando el cens pertenescient a mi que havra corrido porrata. Et porque a mi me plaze darles aquesta gracia de poderlo quitar, quiero que por el dito notario testificant todos los actos sobre ditos, vos ne sia feyto el present reconoscimiento a todos tiempos valedero ${ }^{64}$.

No se tiene noticia documental de cuál fuera la cuantía que de dicho censal correspondía pagar a la aljama judía de Illueca, ni de que se efectuara pago alguno ni tampoco de si, en efecto, ateniéndose a dicha carta de gracia, el escudero les revendió el censo. Pero sí consta que dicha aljama efectuó varios pagos al escudero, con el que estaba obligada en otro contrato censal de ciento veinte sueldos, a pagar anualmente el día 4 de diciembre, por el que el escudero pagó mil quinientos sueldos, y que se redactó en Illueca ${ }^{65}$. Hubo años en los que este censo lo cobró Ochona de Ortubia, personalmente ${ }^{66}$; otras veces fue su hija Beatriz de Ortubia, mujer del escudero bilbilitano Martín de Sayas, la encargada de cobrarlo ${ }^{67}$; luego, a la muerte de Ochona, sería su viuda Leonor Mur quien lo recibiera ${ }^{68}$. Finalmente, ésta reduciría el censo, el 29 de septiembre

${ }^{64}$ Dicho notario y año, fol. 81 .

65 Ante el notario Pedro Ximénez Pardo, que vivía en Arándiga; la fecha aparece en blanco.

${ }^{66}$ El 11 de junio de 1472, en el lugar de Almonacid, el escudero recibió los ciento veinte sueldos de la aljama de Illueca, correspondientes al anterior 4 de diciembre, y otorgó albarán. El 27 de junio de 1479, en Épila, Ochona recibió de los adelantados y de dicha aljama cuatrocientos ochenta sueldos, correspondientes a las pensiones de dicho censo de los años 1475, 1476, 1477 y 1478, y otorgó el correspondiente albarán (Z.APN., Antón de Abiego, 1472, fols. 16v-17, y 1479, fol. 81v).

${ }^{67}$ El 16 de noviembre de 1473, en Épila, sin revocar procuradores, Ochona nombró como tal a su hija, «especialment e expressa a demandar, haver, recebir e cobrar» los dichos ciento veinte sueldos del censo, para hacer albaranes, para pleitos, y con poder de jurar y sustituir (dicho notario, 1473, fol. $70 \mathrm{v}$ ).

${ }^{68}$ El 16 de septiembre de 1482, en Épila, recibió la viuda dicho censo, correspondiente al 4 de diciembre de 1481 (dicho notario, 1482, fol. 95). 
de 1483, en Épila, «considerant en cara seyer rogada de lo infrascripto", para que los adelantados, clavario y aljama "no seades ni finquedes tenidos durant el tiempo de la dicha mi viduydat de dar et pagar a mi por razon del dicho censal", sino cien sueldos anuales el 4 de diciembre; si el pago no se efectuaba dicho día o un mes después, "que la dicha reduccion no valga y siha havida por no fecha, etc.» ${ }^{69}$.

Años después de haber muerto don Jaime Martínez de Luna, cuando era señor de Illueca su hijo, el concejo de cristianos y las aljamas de judíos y moros de Illueca, y los concejos y aljamas de Arándiga, Morata, Chodes, Vilueña, Villanueva, Valtorres y Gotor, lugares de don Pedro Martínez de Luna, junto con él, debían diversos censos a don Pedro de Francia, a su mujer doña Beatriz Ruiz, señores de Bureta, y a sus hijos Isabel y Juan de Francia, de los que eran tutores. Los deudores firmaron una concordia y capitulación con los señores de Bureta, en la que reconocieron que les estaban obligados en ochenta mil sueldos; dicha cantidad la pagarían en dieciséis años, a partir del mes de noviembre de 1474, cinco mil sueldos anuales; el matrimonio que no podía vender la comanda, estaba obligado a otorgar ápoca y cancelarla, una vez pagada. Para reconocer dicha obligación, se reunió el concejo general de cristianos, judíos y moros de Illueca, en la iglesia de San Juan, sin que se especifique quién les avisó. Asistieron por parte judía, los adelantados Sabat Moncati y Juce Carrillo, y Juce Brahembon, Sento Haget, Mosse Franco, Leon Quatorze, Jehuda Ceyt, Daniel Franco, Mosse Repol, Juce Abrullo ${ }^{70}$ «e de sí todo el concejo de cristianos, judios

${ }^{69}$ Las demás obligaciones del contrato censal se mantuvieron (dicho notario, 1483, fols. 93-94v). Pero en Épila, el 29 de septiembre de 1483, Leonor cobró los ciento veinte sueldos de 1482; el 16 de febrero de 1484, los cien de 1483; el 20 de enero de 1485, los cien de 1484; el 2 de mayo de 1487, los ciento veinte de 1486 (dicho notario, 1483, fol. 95, 1484, fol. $16 \mathrm{v}$ y 1485, fol. $10 \mathrm{v}$ ); y el 4 de diciembre de 1490, su procurador el notario Antón de Abiego cobró otros cien (L.A.APN., Martín Ramo, 1490, fols. $155 \mathrm{v}-156 \mathrm{v}$ ).

70 Por parte cristiana, el justicia Juan Urbano, los jurados Antón Urbano y Juan Misia, y Martín Fortuño; por parte mora, el alamín Ibrahim el Alamin, el alfaquí Jayel Almalech, el jurado y procurador de la aljama Ali el Arandino, y Jayel el Moscabida (sic), Juce el Texedor, Mahoma el Rey, Ali el Aladi, Ali el Cantarero, menor, Avdalla de Gali, Juce el Cantarero, Ibrahim el Rey, Ibrahim el Trampero, Mahoma Moscabida, Calema Sisanta, Ali el Ollero, Mahoma el Morisco, Mahoma de Spada, Hamet el Rey, Hamet el Texedor e Ibrahim de Moscabida. 
y moros de la villa». El 20 de octubre de 1475, en Bureta, los señores del lugar don Pedro y doña Beatriz reconocieron que habían recibido de don Pedro Martínez de Luna y de los dichos concejos y aljamas los cinco mil sueldos, correpondientes a 1474. Cuando se hubieran pagado veinticinco mil quinientos setenta y cinco sueldos, por un lado, y siete mil quinientos, por otro, el matrimonio vendería a don Pedro Martínez de Luna censales atrasados; así se haría a medida que se fuera pagando; entregada la totalidad de la comanda, don Pedro de Francia y su mujer le revenderían todos los censos en los que él y sus lugares estaban obligados ${ }^{71}$.

Un año después, en 1476, el señor de la baronía de Illueca, don Pedro Martínez de Luna, y el señor del vizcondado de Rueda y de la villa de Épila, don Lope Ximénez de Urrea, trataban el matrimonio de sus respectivos hijos, don Juan Martínez de Luna y doña Catalina de Urrea. El 24 de abril de dicho año, en Zaragoza, acordaron nombrar árbitros para llegar a un acuerdo a los señores don Felipe de Castro y don Miguel Gilbert, quienes emitieron sentencia el mismo día de su nombramiento. Como consecuencia de la sentencia, tuvieron que obligarse ambos señores y sus villas y vasallos de Illueca y Épila, respectivamente, en una comanda recíproca de quince mil florines de oro, y reconocer: los de Illueca que tomarían por señor a don Lope, y los de Épila, que harían lo mismo con don Pedro, en el caso de que, cuando tuvieran edad de contraer matrimonio doña Catalina y don Juan, no lo hicieran. El notario comunicó la sentencia, en Illueca, a los padres de ambos contrayentes. El 22 de julio, lo hacía a don Lope Ximénez de Urrea y a su mujer doña Catalina, y cinco días después, el 27, a don Pedro y a su mujer doña Deanira, quienes la aprobaron y loaron. Luego, don Pedro Martínez de Luna dio licencia a los justicia, jurados, concejo de cristianos y aljamas de judíos y moros de su lugar de Illueca, para que se obligaran en comanda a don Lope en quince mil florines de oro, lo mismo que días antes, el 22, habían hecho los vecinos de Épila, cristianos, judíos y moros; obligándose, además, los oficiales a prestar homenaje y vasallaje. A continuación, don Pedro otorgó tener en comanda de don Lope quince mil florines de oro; obligó su persona y bienes, su castillo y villa de Illueca, sus

\footnotetext{
${ }^{71}$ Z.APN., Antón Maurán, 1475, fols. 1-21.
} 
«rendas e drechos», sus términos y los hombres y vasallos de ella. Después, el 27 de julio de dicho año, en Illueca, «a la puerta de la eglesia mayor ${ }^{72}$..., en do otras vegadas por semblantes e otros negocios se costumbran plegar», avisados por "voz e crida» del corredor público, nuncio y jurado Antón Salabert y por orden del señor don Pedro, el justicia y los jurados de la villa, se reunieron el concejo de cristianos ${ }^{73}$, la aljama de moros ${ }^{74}$ y la de judíos; asistieron por parte judía, los adelantados Sabat Moncati y Juce Carrillo, mayor, y Leon Quatorze, Jehuda Ceyt, Caçon Cogulla, Juce Carrillo, menor, Simuel Franco, Simuel Çarfati, Abraham Ceyt, Junez Haym, Abraham Najares, Simuel Alpastan, Mosse Carrillo, rabí Acach de Calo, Acach Alguer, Hahim Franco, Mosse Repol, Juce Haym y Sento Najares; vecinos de la villa. Todos de acuerdo, con licencia del señor y ante notario, juraron, cada uno según su ley, y prestaron "sagrament de homenage de manos e de boca" los cristianos, y los judíos y moros sólo "de manos e beso en el hombro, en poder» del escudero Ochona de Ortubia, procurador de don Lope Ximénez de Urrea ${ }^{75}$, que hasta la "restitucion de la carta de comanda" de los quince mil florines de oro, obedecerían y tendrían a don Lope y a sus sucesores por señores verdaderos del castillo y villa de Illueca, frutos y rentas, y no a don Pedro Martínez de Luna ni a los suyos, y reponderían, en dicho caso, a don Lope de las rentas hasta que se devolviera la comanda; obligaron su persona y bienes a cumplirlo ${ }^{76}$. Finalmente, don Pedro reconoció a don Lope dicha comanda, pero aquélla no tendrían validez cuando don Juan se casara con doña Catalina, transcurridos ocho días desde que pudiera hacerlo. El

\footnotetext{
72 O en la plaza «devant la dita eglesia mayor».

73 Antón Doncellón, lugarteniente de alcaide de la dita villa, «por la senyora», Asensio Inés, lugarteniente del justicia Juan Urbano, el jurado Antón Urbano, y Juan de Haro, Pedro Suárez y Antón Montero.

${ }^{74}$ El alamín Brahem el Aladi, los procuradores y jurados Ali el Arandino y Haye Buscavida, el alfaquí Haye Almalech, y Mahoma el Tejedor, Mahoma el Rey, Brahem de Buscavida, Mahoma el Tejedor (sic), Mahoma el Tacanyero, Mahoma el Eli, Mahoma el Arandino, Juce el Tejedor, Brahem de. Spada, Ali de Calem, Mahoma Buscavida, Ali Alfaquen, Ali el Ollero, Mahoma Almaleyco, Farax el Aladi y Ali el Aladi.

${ }^{75}$ Según poder hecho en Épila, el 24 de julio de 1476 , ante el notario Antón Maurán.

76 Z.APN., Antón Maurán, 1476, fols. 573-586v; testigo con un cristiano y un moro de Jarque, el judío de Arándiga Sento Arueti.
} 
siguiente 2 de agosto, en Épila, don Lope reconoció tener de don Pedro dicha comanda, pero aquélla sólo se podría demandar y exigir en caso de que doña Catalina de Urrea, esposa de don Juan Martínez de Luna, estuviera en edad legítima de contraer matrimonio $\mathrm{y}$, a los ocho días de poder contraerlo, no lo tomara por esposo ${ }^{7}$.

Don Pedro Martínez de Luna, cuya muerte le sobrevino en 1482, cuando sus dos hijos eran menores de edad, nombró tutores y curadores de su hijo mayor, el pupilo don Juan Martínez de Luna, a su mujer doña Deanira de Luna y Lanuza, a don Felipe de Castro y de Pinos, señor de la baronía de Estadilla, al citado don Lope Ximénez de Urrea y al caballero y consejero del Rey y justicia de Aragón mosén Juan de Lanuza ${ }^{78}$.

El 3 de febrero de 1483, en la plaza de Illueca, delante de la iglesia, los procuradores de los tutores del menor don Juan Martínez de Luna tomaron posesión del lugar, en nombre del pupilo, ante el concejo general de cristianos, moros y judíos, como era costumbre hacer a la muerte del titular del señorío. Asistieron, entre otros, el alcaide Antón Doncellón, el justicia Juan Urbano ${ }^{79}$, los jurados Pedro Sanchón y Juan Inés ${ }^{80}$, el alamín Brahem de Aladi, los procuradores Yuce de Gali y Mahoma Tacanyero, los jurados Ali de Guesa, Hamet el Texedor y Hamet el Tacanyero ${ }^{81}$, los adelantados Abraham Bon y Simuel Alpastan, el procurador Leon Quatorze, y Hacan Alguer, Mosse Quatorze, Abraham Ceyt, Simuel Bon, Junez Haym, Mosse Carrillo, Abraham Najares, Juce Jarando, Daniel Franco, Mayr de Calo, Hacan Moncati, Simuel Franco, Abraham Ceyt, mayor, Mosse Najares, Abraham Abendaut, Juce Carrillo y Haron Cida ${ }^{82}$.

77 Dicho notario y año, fols. 587-589.

78 Los tres señores nombraron procuradora suya a la viuda doña Deanira, el 22 de enero de 1483, en Zaragoza, y el 26 de marzo de dicho año, en el castillo de Illueca, le dieron licencia para actuar como tutora y curadora.

79 En ocasiones, el apellido Urbano aparecen escrito Burbano.

${ }^{80}$ Además de Antón Montero, Antón Burbano o Urbano y Juan de Ejea.

81 Además de Mahoma el Tacanyero, Mahoma Buscabida, Avdalla de Gali, Juce el Cantarero, el alfaquí Haye Almalequa, Mahoma el Tacanyero, mayor, Ali el Ollero, Brahem el Trampero, Mahoma el D'Ayca, Hamet el Teçador, Hamet el Cantarero, Ali el Mastrali, Hamet el Rey y Brahem de Buscabida, menor.

${ }^{82}$ Z.APN., Antón Maurán, 1483, fols. 3v-4v; fueron testigos con dos cristianos, el judío Jehuda Ceyt, el corredor Antón Faver y el moro Ali de Aladi. 
La mayoría de edad del heredero del señorío de Illueca, don Juan Martínez de Luna, duró poco. En julio de 1489 tuvo lugar su desgraciada muerte en el cerco de Baza ${ }^{83}$; "no tenia veynte y un años, y era ... muy favorecido del Rey, y amado de toda la Corte» ${ }^{84}$. E1 18 de dicho mes, el rey don Fernando comunicó a doña Deanira el fallecimiento de su hijo mayor, en carta escrita desde su real sitio de Baza ${ }^{85}$. A la muerte de don Juan, el señorío pasó a su hermano don Jaime Martínez de Luna, pero el consuelo que el rey esperaba que doña Deanira encontrara en este hijo no iba a durar mucho, aunque al pertenecer a la señora la mitad usufructuaria de parte del señorío, los intereses de madre ${ }^{86}$ e hijo iban a ser los mismos. A la señora de Morata, doña Deanira de Luna y de Lanuza, le tocaría vivir un pleito con su hijo don Jaime, del que sería nombrado árbitro el justicia de Aragón mosén Juan de Lanuza, hermano de dicha señora.

Pocos meses después de producirse la muerte de don Juan Martínez de Luna, concretamente el 23 de diciembre de 1489, en Almería, «en virtut de una gracia e merce», el rey don Fernando concedió a don Jaime, "nuestro criado y camarlengo cuya se dize ser la dita casa e varonia de Illuequa", todos los bienes, muebles e inmuebles, derechos, créditos, rentas, nombres e acciones que fueron del difunto Juan Fierro y de su mujer Beatriz de Azafet, ciudadanos de Calatayud, "por los inquisidores de la heretica pravedat denunciados de los crimines de heregia y apostasia e a la camara e fisco de su alteza confiscados» ${ }^{87}$.

${ }^{83}$ A dicho cerco se refiere J. ZurITA, Anales, 4, libro XX, cap. LXXXI, pág. 359; y M. A. Ladero Quesada, Milicia y economía de la Guerra de Granada: El cerco de Baza, Valladolid 1964.

${ }^{84}$ Señala J. Zurita, Anales, dicho tomo, libro y capítulo, pág. 360.

${ }^{85}$ Transcribí dicha carta en E. MARín PADLlLA, Relación judeoconversa durante la segunda mitad del siglo XV en Aragón: la Ley, Madrid 1986, pảg. 24, nota 38.

${ }^{86}$ Fueron deudores de doña Deanira o Dianira, señora de Morata, entre otros residentes en Calatayud, los judíos bilbilitanos maestre Mosse Alpastan, su hermano Abraham Alpastan, Jehuda Gargonia, Abraham y Mosse Avayut, Vidal Quatorze y Juce Hayat.

87 «Segun consta de la dicha gracia por provision de mano de su alteza firmada e por el magnifico mossen Luys Gonçalvez, secretario, referendada, con signo de registrada e con el sello real en el dorso de aquella sellada». Gracia que el rey notificó el mismo día de su otorgamiento a Juan Ruiz, receptor general de todos los bienes, rentas y derechos confiscados por la Inquisición por el delito de herejía y apostasía en las ciudades y diócesis de Zaragoza y Tarazona, con todas las garantías 
Cuando ya era conocido el edicto de expulsión de los judíos, concretamente el 13 de mayo de 1492, en Illueca, con permiso de don Jaime Martínez de Luna dado el día anterior, se reunió el concejo de cristianos y las aljamas de judíos y moros de la villa en la plaza de los cristianos, como era costumbre. Los convocó por «tanymiento de canpana e publico pregon» el corredor público Martín Inés, por orden del justicia Juan Inés, en cuanto a la convocatoria de los cristianos; por la del alamín Brahem el Aladi, en cuanto a la de la aljama mora; y por la del adelantado Acach Alguer, en cuanto a la convocatoria de la aljama judía. El motivo de que los vecinos de la villa, cristianos, moros ${ }^{88}$ y judíos - los adelantados Mosse Quatorze y Acach Alguer, el procurador Acach Moncati, y Salamon Ceyt, Abraham Ceyt, Caçon Cogulla y Salamon Ocanya-, se reunieran dicho día, no fue otro que manifestar que habían recibido en comanda del ciudadano de Zaragoza Antón de Ervás ${ }^{89}$, alcaide del lugar de Brea, siete mil sueldos, de los que respondieron con «todos los ganados e adulas, grosos e menudos, de los ditos concexo e aljamas, etc.». Después de que los de Illueca nombraran procuradores a cuatro notarios cristianos de Zaragoza, juraron, ante el notario, no pleitear ${ }^{90}$. A continuación, Antón de Ervás prometió y se obligó a darles «los contractos, censales e otros qualesquiere actos dependientes del deudo, si quiere, quitamiento de Pedro de Francia, a los pueblos e tierra del dicho señor don Jaime» o a quien tuviera poder en ellos ${ }^{91}$. La alusión al «deudo, si quiere,

a favor de don Jaime. El receptor otorgó «remision et relexacion" a éste de todos los bienes del matrimonio bilbilitano, pertenecientes a su alteza, el 11 de febrero de 1490 , en Zaragoza.

88 Por parte cristiana: el justicia Juan Inés, los jurados Pedro Sánchez y Pedro Ciria, y Antón Montero, Juan Urbano, Ferrán Cabeza, Asensio Inés y Juan Mateo. Por parte mora: el alamín Ybrahem el Aladi, Hamet el Rey, el procurador Homar Cantarero, Hamet el Texedor, mayor, Mahoma el Arandino, el barbero Ali el Arandino, Mahoma el Morisco, Ali el Ollero, Avdalla de Gale, Ali el Parquino, Mahoma Tacanyero, Hamet el Hebi, Mahoma el Muelo, Ali de Gale, Mahoma Almalich, Ybrahem de Cey, Mahoma Moscavida, Ybrahem el Ollero, Ali el Aladi y Yuce el Cantarero.

89 A él me referí en E. Marín Padilla, «Antecedentes», pág. 559.

90 Los cristianos "por la señal de la cruz» y los santos evangelios; los moros por «ville alladi, etc.», ante Yuce el Caldero e Ybrahem el Aladi; y los judíos por Dios y los mandamientos de la ley de Moisés, ante Mosse Olbalafio.

91 Z.APN., Gonzalvo de Sayas, 1492, fols. 22-24v; testigos por el otorgamiento de los de Illueca: el zapatero Martín Crespo, el pintor Juan Rodríguez, el moro Yuce el Calderero y el judío Mosse Olbalafio. 
quitamiento" de Pedro de Francia, induce a pensar que el débito que tenían contraído algunos lugares del señorío de los Martínez de Luna con los señores de Buretá, al que con anterioridad se aludió, pudo comprarlo el zaragozano Antón de Ervás.

La comanda de siete mil sueldos a favor de dicho Antón en la que, además del concejo cristiano y las aljamas judía y mora de Illueca, también se obligaron la aljama mora de Gotor ${ }^{92}$, la aljama mora de Purroy ${ }^{93}$, el concejo de cristianos y la aljama mora de Villanueva ${ }^{94}$, la aljama mora de Chodes ${ }^{95}$, y la aljama mora de Morata ${ }^{96}$, e, incluso, el concejo cristiano y la aljama mora de

${ }^{92}$ El 13 de mayo y también con permiso de don Jaime, se reunió la aljama mora de Gotor, convocada por el corredor del lugar Ybrahem de la Mora, por orden del alamin Ybrahem Quinyaceyt. Asistieron: dicho alamín, el alfaquí Ybrahem de Calema, el procurador Mahoma el Corço, Ali Marrich, Ali la Puerta, Mahoma Çalema, Haye el Fuero, Yuce Gualit, Yuce Çalemo, Hamet el Calvo, Mahoma el Carnicero, Ali Laziach, Ybrahem de Molina, Mahoma el Royo, Mahoma Domalich, Hamet el Carnicero, Farax el Frayron y Hamet de Gale, vecinos del lugar (dichos notario, año y fols; testigos de este otorgamiento: los labradores Juan Inés y Martín Crespo, e Ybrahem el Aladi, moro que vivía en Morata).

${ }^{93}$ Reunida el 14 de mayo en la plaza, convocada por el corredor Mahoma el Ollero, por orden del alamín Ybrahem de Meçot y con el permiso de don Jaime. Asistieron los vecinos: dicho alamín, los jurados Ali de la Mora y Yuce el Hadari, y Yuce el Royo, Avdalla el Hadari, Yuce el Tudesco, el alfaquí Mahoma el Raquero, Mahoma el Hadari y Dorramen de Mecot; quienes prometieron pagarla y juraron no pleitear (dicho notario y año, fols. 24v-25; testigos: Martín Magallón, el alamín de Illueca Ybrahem el Aladi e Ybrahem el Majon, también vecino de esta villa).

${ }_{94}$ El 14 de mayo reunidos en la plaza, convocados por el corredor Mahoma el Cantarero, por orden del justicia y con permiso de don Jaime. Asistieron los vecinos: el notario y justicia Pedro Pardo y Miguel Gascón, por el concejo cristiano; y el alamín Yuce el Alamín, Hilel Cantarero, Mahoma Rebollo, Mahoma Cay, el alfaquí Mahoma de Ricli, Ybrahem Redondo y Mahoma Lancero, por la aljama mora; todos prometieron pagarla y juraron no pleitear (dicho notario y año, fol. $25 \mathrm{v}$; testigos: el vicario mosén Antón Marín, el vecino de Arándiga Martín Magallón, el citado alamín de Illueca Ybrahem el Aladi y el vecino de Purroy Yuce el Royo).

${ }^{95}$ El 14 de mayo reunida en la puerta del lugar, convocada por el jurado Mahoma Jamila. Asistieron los vecinos: Farax de Cayr, lugarteniente de alamín, Ali el de la Mezquita, el jurado Yuce Cayr, Mahoma de Arondi, Ybrahem de Abocach, Mahoma Migeren, Yuce Arondi y Yuce Haxex; quienes prometieron pagarla y juraron no pleitear (dicho notario y año, fol. 26; testigos: el escudero del señor don Jaime, Juan de la Puebla, y los moros del lugar Mahoma Abocach y Mahoma el Calbo).

${ }^{96}$ El 15 de mayo reunida en la plaza, convocada por el corredor Yuce el Royo, por orden del alamin y con permiso de la señora del lugar doña Deanira de Luna y Lanuza para que se obligase "con la otra tierra mia e de don Jaime, mi fixo". Asistieron: el alamín Mahoma el Ferrero, el jurado Doramen de Cay, Ali el Gallego, mayor, Mahoma el Romo, Mahoma el Horio, Ybrahem de Zeyne, Mahoma Migen, Mahoma de Arandiga, Ybrahem Crespo, Hamet el Royo, Ali el Gallego, menor, Lop 
Arándiga con otra comanda de setecientos sueldos al mismo alcaide de Brea ${ }^{97}$, se canceló, junto con ésta, el 12 de marzo de 1498, en Zaragoza, ante el notario Miguel de Villanueva. Se desconoce el modo en que se repartió la parte que correspondía a los judíos de Illueca, cuando éstos fueron expulsados, aunque algunos se convirtieran y siguieran pagando su cuota. Consta, sin embargo, que en 1492 cuando Francisco de Torres demandó a don Jaime Martínez de Luna, como heredero de don Pedro, determinadas cosas, una de ellas la fundamentaba así:

Item apres estando en casa de doña Johana de Luna con grande instancia ampro al dicho Francisco de Torres de otros XXX florines doro que tenia empenyada cierta plata en poder de Anthon d'Ervas e yo la quite y ge la dic. Et me promisso e juro de pagarmelos todos los LX florines doro; sabenlo Anthon d'Ervas e Loys de Luna e todos de su casa.

Conviene recordar que el 18 de octubre de ese mismo año, se entregaron al notario los capítulos matrimoniales de don Jaime Martínez de Luna y doña Catalina de Urrea, hija de don Lope Ximénez de Urrea y nieta del virrey de Sicilia. Pero como doña Catalina «fue sposada con el noble don Johan ... por paravlas de presente ..., el present matrimonio por causa del dicho inpediment no puede haver conclusion» ni hacerse por palabras «de present», por la Iglesia y consumado «sinse dispensacion obtenida de nuestro santo padre».

de Cetina, Mahoma el Gallego, mayor, Avdalla de Arándiga, Yuce de Huesa y Yuce el Gallego; quienes admitieron haber recibido la comanda con «toda la otra tierra», prometieron pagarla y juraron no pleitear (dicho notario y año, fols. 26v-27; testigos: Agustín de Saviñán, en servicio de Alonso Salcedo, paje de Diego de Orellano, y los vecinos del lugar Mahoma Haquen y Mahoma de Obecar).

${ }^{97}$ El 16 de mayo reunida en la puerta de la iglesia, convocada por el corredor Aziz Calema y con permiso de don Jaime. Asistieron los vecinos: el justicia Martín Ximénez, los jurados Juan Trasobares y Juan Felipe, y Juan de Calcena, Pedro Villanueva, Pascual de Marquesa, Domingo Royo, Bartolomé Fraire, Jaime Calbo, Pascual Marín y Antón Valero, además del alamín Mahoma Dolagy, Avdalla Haxex, Ybrahem de Real, Ali Pastor y Yuce el Fuestero; todos otorgaron haberla recibido, nombraron procuradores y juraron (dicho notario y año, fols. $27 \mathrm{v}-28$; testigos: el vicario mosén Tomás Aldeano, el clérigo Martín López y el moro Mahoma Haxex, que vivían en la villa). 


\section{Relaciones sociales}

La documentación no recoge conflicto alguno entre los miembros de la comunidad judía, ni con los demás convecinos cristianos y moros residentes en la villa. Las relaciones entre los miembros de las tres «leyes" religiosas o entre el concejo cristiano y aljamas judía y mora, parecen basadas sólo en motivos económicos, como en el caso de venta de censos, deudos o recibo de comandas, o cuando había cuestiones que afectaban por igual a las tres comunidades, como sucedió en 1490 , cuando se trató de nombrar jueces menores de la Hermandad de la villa.

El 4 de octubre de dicho año, tuvo lugar una reunión en Illueca, a la que habían sido convocados el concejo de cristianos, la aljama de moros y la de judíos, por el corredor público Martín Inés. Asistieron a la misma cristianos ${ }^{98}$, moros ${ }^{99}$ y por parte judía, el adelantado Caçon Cogulla, junto con Abraham Ceyt, Juce Ceyt, Jaco Ax, Mayr de Calo, Juce Bon, Jehuda Ceyt, Mosse Najares, Haron Cida, Barzilay Levi, Simuel Franco y Acach Ceyt, «aljamantes». Todos los reunidos, sin discrepancia alguna, «justa el tenor de la capitulacion de la santa hermandat en el Regno de Aragon", eligieron y nombraron jueces menores de la Hermandad de la villa a Juan Urbano, juez menor, y, como lugarteniente suyo, a Pedro Sánchez. Los nombrados juraron por Dios, sobre la cruz y los cuatro evangelios, ante los jurados y regidores cristianos; y prestaron

homenage de manos et de boca justa tenor de la dicha capitulacion de hermandat en poder de los dichos officiales de haversse bien y lealmente en sus officios, cada uno lo que le toquara et que por amor, temor, favor, sobornacion, etc., no dexara de exsecutar et conplir la dicha capitulacion et que por disimulacion, etc., ni en nenguna otra manera no dexaran de conplir lo que a sus officios tocara et son tovidos justa tenor de la dicha capitulacion de hermandat.

\footnotetext{
98 Asistieron los jurados Pedro Sánchez y Juan Asensio, y Juan Burbano, mayor, Antón Burbano, Asensio Inés, y Pedro Suárez, vecinos de la villa, "concellantes»

99 Asistieron el jurado Hamet el Sperado, y Mahoma el Arandino, Yuce el Arandino, Mahoma el Catanyero, Mahoma el Cantarero, Ybrahim de Buscavida, Mahoma Mançor y Ybrahim de Almalequa, «aljamantes».
} 
Hecho el juramento y homenaje, requirieron al notario para que levantara acta pública ${ }^{100}$.

No consta qué dificultades tuvo que vencer la Hermandad para que entraran en ella los lugares del señorío de los Martínez de Luna, ni cuál fue el parecer de don Jaime al respecto, pero por entonces se produjeron los graves incidentes que alteraron la vida de quienes residían en el señorío de los Martínez de Luna, en calidad de vasallos y vecinos, aún antes de que los de Arándiga fuesen de la Hermandad. Las relaciones de cristianos, judíos y moros con sus señores se tensaron hasta límites insospechados, aunque dependieran directamente de ellos. El gran poder que la familia tenía no fue óbice para que, llegado el caso y cuando creyeron que se les exigía un pago indebido, se unieran todos en contra del señor.

El motivo de enfrentamiento de vasallos cristianos, judíos y moros con don Jaime Martínez de Luna, trató de aclararlo Agustín de Saviñán, procurador de dicho señor, el 24 de julio de 149l, en Illueca, al comparecer ante el justicia de la villa Juan Inés y manifestar «que como se entiendiesse ayudar delante de qualesquiere juges o señores de algunos testimonios", lo requería para que citara como testigos a Antón Montero, Pedro de Viña, Juan Urbano, Martín Crespo, Farax el Sperado y Acach Alguer, que allí residían. Una vez citados, los testigos juraron, cada uno según su respectiva «ley» decir la verdad.

Antón Montero explicó: que el sábado 5 de junio el señor don Jaime tomó presos a los judíos de Arándiga y él, como justicia, hizo ir a la gente de Illueca a Arándiga, a «fazer lo que les mandasse el señor et assi por su mandado aquel mismo sabado la dicha gente traxo bienes de los dichos judios" a Illueca; que los de Arándiga, junto con otros hombres de la "otra tierra del señor, se legaron mucho ante que fuessen de la ermandat, en Ia iglesia" de Illueca; que allí

se juramentaron todos et dieron poder a ciertas personas que no consintiessen en pagar un deudo de Simon que les demandavan sino

100 L.A.APN., Miguel Contín, 1490, fols. 65v-66; testigos: el cristiano de Arándiga Martín Fortuño, el judío vecino de Almonacid de la Sierra Sento Cohem y el alfaquí de Calatayud Muça el Alfaqui. 
que gastassen sobre ello quanto pudiessen, pues que pagado estava; y que esto es verdat.

El moro Farax el Sperado contó: que el sábado que el señor apresó a los judíos de Arándiga, mandó a todos sus vasallos que allí estaban, que «ocupiessen los bienes de los dichos judios e assi los dichos vasallos los tomaron e ocuparon por su mandado"; y que él estuvo, junto con "otros de la otra tierra del señor don Jaime», cuando se reunieron todos en la iglesia de Illueca, «mucho ante que los de Arandiga fuessen de la ermandat", donde acordaron "todos e dizeron unos a otros palavra que, en un deudo de Simon que el señor les pidia, no haziessen cosa ninguna ni lo pagassen, pues que era pagado».

Pedro de Viña manifestó que ese sabado, presos los judíos de Arándiga, los vasallos de don Jaime "ocuparon e trayeron todos sus bienes» a Illueca, por mandato suyo.

Martín Crespo contó lo mismo y aclaró que se juntaron todos en la iglesia de Illueca y acordaron no pagar «un deudo quel señor les pedia de Simon, sino que harian todo lo que Arandiga fiziesse».

Juan Urbano explicó los acontecimientos igual: que en la iglesia de Illueca "se llegaron toda la tierra" y que, pues el deudo "era pagado, sino que harian todo lo que los de Arandiga hiziessen; y que por esto disputaron tres personas, las quales no se acuerda».

Finalmente, interrogado el judío Acach Alguer, sus palabras parecen más claras: apresados los judíos el sábado, oyó decir que el señor mandó ese día

a los otros sus vasallos que tomassen los bienes de los dichos judios e assi vio los truxieron [a] Illuequa; e con esto dize que toda la tierra se junto en la iglesia de Illuequa, mucho ante que los de Arandiga fuessen de la ermandat, acerqua del deudo de Simon, e que este testigo porque dizia se cupiesse en servicio del señor, lo echaron de alli; e que stando todos delante el señor oyo dezir ad Anton Montero, justicia que era entonce, que estando todos delante el señor don Jayme, que dixo: yo no puedo hablar nada, porque soy juramentado con los otros.

También compareció el moro de Gotor Mahoma el Royo, pero su testificación no quedó recogida ${ }^{101}$.

\footnotetext{
${ }^{101}$ Z.APN., Gonzalvo de Sayas, 1491, papel suelto; testigos: Juan Burbano, menor, y el vicario de Illueca mosén Pedro Martínez.
} 
¿A qué jueces y señores, ante quienes «se entiendiesse ayudar», se refirió el procurador Agustín de Saviñán en su comparecencia ante el justicia de Illueca? ¿Hubo un juicio sobre el caso ante tribunales aragoneses? No consta nada al respecto, pero sí que la seguridad respecto al impago de dicho censo se la habia dado a los vasallos de don Jaime un documento redactado meses antes. El 15 de septiembre de 1490, en Arándiga, ante el justicia Martín Ximénez y a instancia y requerimiento del jurado Pedro Marcos, del procurador de los judíos Abraham Ceyt y del procurador de los moros Ali el Pastor, el corredor Brahem el Pastor citó al judío y vecino de allí Sento Arruet. Delante del justicia, Sento juró, por lo diez mandamientos de la ley de Moisés y "prendio quinyan segunt ley de judios en poder» de Abraham Çarfati, decir la «verdat de lo que seria interrogado et que por amor, temor, etc., no dira sino el fecho de la verdat, etc.». Una vez prestado el juramento, Sento explicó que «toda la tierra del senyor don Pedro de Luna, quondam, fizo servicio al dicho senyor ... de trenta mil sueldos pora quitar el censsal de Simon de Santa Clara» ${ }^{102}$; cantidad que «la dicha tierra havia de pagar en siete anyos y medio». Añadió Sento «que él de voluntat del dicho senyor fue sacado en receptor» para recibir la cantidad y

que la tierra ha pagado por medio suyo la dicha quantidat en siete tandas y media, si quiere, anyos et haun han pagado una tanda mas que son ocho anyos y ochos tandas, la qual quantia él sabe ha recebido el dicho senyor y la senyora su muxer o se ha pagado a quien ellos ham mandado.

Sento terminó su exposición insistiendo en

que la tierra no deve cosa alguna, excepto que deve el lugar de Gotor cient sueldos y el lugar de Viluenya otros cient sueldos et la villa de Arandiga dotze sueldos y medio et que todo el resto han pagado y que no deven nenguna cosa.

\footnotetext{
${ }^{102}$ A dicho converso bilbilitano me he referido en varias ocasiones; véase $\mathrm{E}$. Marín Padilla, Relación, págs. 23, 85-87, 92-93, 109 y 148-149.
} 
Oído su testimonio, los presentes requirieron al notario para que levantara acta pública ${ }^{103}$.

¿Qué pretendían con este requerimiento el jurado cristiano Pedro Marcos, el procurador de los judíos Abraham Ceyt y el procurador de los moros Ali el Pastor? ¿Sólo tener el testimonio del judío Sento Arruet, nombrado receptor del censal del converso bilbilitano Simón de Santa Clara, por el señor don Pedro Martínez de Luna, para tener seguridad respecto a los pagos hechos por las comunidades cristianas, judías y moras del señorío? La documentación no vuelve a referirse al caso, por lo que se ignora cómo terminó la cuestión, qué pasó con los judíos de Arándiga apresados, precisamente un sábado, de qué modo se les devolvieron los bienes que por orden de don Jaime se trajeron ese día a Illueca, indebida e injustamente, y cómo la tranquilidad volvió al señorío de los Martínez de Luna, meses antes de que se promulgara el edicto de expulsión de los judíos del reino de Aragón.

Pienso que, tal vez, don Jaime Martínez de Luna fue hombre de intransigente carácter y temperamento fuerte, porque también las diferencias surgidas entre él y su madre doña Deanira hicieron necesario el nombramiento de un árbitro, asignación que recayó el 2 de enero de 1494, en la persona del justicia de Aragón mosén Juan de Lanuza, lugarteniente general en el principado de Cataluña y condados de Rosellón y Cerdeña, y hermano de dicha señora. El tiempo fijado para emitir la sentencia, que podía prorrogarse, fue el mes de enero y la pena por incumplimiento, cinco mil florines de oro; la sentencia se entregó al notario en el plazo fijado.

En cuanto a los contactos entre la comunidad judía de Illueca y otra comunidad hebrea del señorío de los Martínez de Luna, la de Arándiga, fueron frecuentes, como se ha visto. Por lo que se refiere a los mantenidos con otros judíos del reino de Aragón, en menor grado hubo contactos con los de La Almunia de Doña Godina, pero sobre todo con los judíos y conversos bilbilitanos con los que mantenían lazos de parentesco: Acach Alguer, cuyo padre estaba emparentado con la mujer de Pablo de Daroca; Abraham de Calo, de Illueca, era hermano de Salamon de Calo, de Calatayud; y

${ }^{103}$ L.A.APN., Miguel Contín, 1490, fols. 64-64v; testigos: Martín de Trasobares, el judio Abraham Çarffati y el alamín Mahoma Dolaziz, todos vecinos de Arándiga. 
Mosse Quatorze, de Illueca, era hijo de Salamon Quatorze, de Calatayud. Otras veces, las relaciones con los bilbilitanos eran de amistad, económicas o de negocios. A partir del 1458, cuando «fuyeron por la peste mucha gente» de Calatayud a Illueca, algunos conversos aprovecharon sus charlas con los judíos de la villa, para comentarles sus más íntimos sentimientos y pensamientos religiosos que, con el tiempo, conocería el tribunal del Santo Oficio de la Inquisición y que pagarían muy caro los que vivían en el tiempo de su proceso; más tarde, en sus frecuentes visitas a Illueca por asuntos propios, los conversos solían acudir a casas de judíos de la villa donde eran invitados a comer, como se señalará en el apartado de familias.

[Continuará] 